\title{
Syntheses, spectral characterization, single crystal X-ray diffraction and computational in gas and solid phases studies on chloro- acetic acid $N^{\prime}$-(2- hydroxy-naphthalen- 1-ylmethylene)- $N$ - [4-(3-methyl-3-phenyl-cyclobutyl)-thiazol-2-yl]-hydrazide
}

\author{
Tuncay Karakurt ${ }^{1}\left[\right.$ D $\cdot$ Muharrem Dinçer $^{2} \cdot$ Alaaddin Cukurovali $^{3}$
}

Received: 20 January 2020 / Accepted: 28 February 2020 / Published online: 7 March 2020

(c) Springer Nature Switzerland AG 2020

\begin{abstract}
In this study, the molecular structure of single crystal containing Schiff bases has been characterized by X-ray diffraction, NMR, IR and UV-Vis spectral techniques and compared with similar molecules in the literature. For the purpose of supporting X-ray results, geometric parameters and spectroscopic studies of the title compound were theoretically performed by Hartree-Fock and density functional theory methods. In addition, the title compound's molecular energies, Mulliken-ESP-NPA-Hirshfeld charges, molecular electrostatic potential surface, Frontier orbitals and thermodynamic properties to elucidate intermolecular interactions were calculated. All the calculations in gas and solid phases were carried out using Gaussian 09 and Quantum Espresso programs. It was found that the studies of X-ray are more compatible with the calculations made in the solid phase.
\end{abstract}

Keywords Schiff bases · X-ray · Quantum Espresso · DFT - Thermodynamic properties

\section{Introduction}

Aromatic heterocycle compounds have attracted more attention than poly ring cyclic aromatic compounds containing only carbon atoms, since they are very common in nature. Heterocyclic compounds also contain both carbon atoms and other atoms such as N, $\mathrm{S}$ and $\mathrm{O}$ in their structure. Thiazoles are also of the class of heterocycle compounds. In a ring of five, this compound is called thiazole if the sulfur and nitrogen atoms are in position 1 or 3 . Many antibiotics and biomolecules containing thiazole and its derivatives are known to have biological importance. The compounds with thiazole ring have applications in pharmacology such as allergies [1], schizophrenia [2], hypertension [3], anti-HIV [4], anti-bacterial [5], anti-thrombotic activity [6], anti-protozoal [7], anti-helminthic [8], antimicrobial [9]. Furthermore, 2-aminothiazoles exhibit potential activity in many human cancer cell lines [10-13]. Thiazole rings are used as starting materials in many areas of chemistry. In addition, some thiazole compounds are used in the paint industry and in agriculture [14]. Cyclobutanes, which have a ring system with four carbon atoms, are organic compounds. There is bond tension in the cyclobutane ring, and because of this tension, the rings can easily react and be converted to straight-chain compounds. Furthermore, this tension makes the molecule more stable conformation by puckering the cyclobutane ring. Their carboxylic acid derivatives have antidepressant activity and liquid crystal properties. They are used

\footnotetext{
$\triangle$ Tuncay Karakurt, tuncaykarakurt@gmail.com | ${ }^{1}$ Department of Chemical and Process Engineering, Faculty of Engineering-Architecture, Kırsehir Ahi Evran University, Kirsehir 40100, Turkey. ${ }^{2}$ Department of Physics, Faculty of Arts and Sciences, Ondokuz Mayis University, Kurupelit, Samsun 55139, Turkey. ${ }^{3}$ Department of Chemistry, Faculty of Science, Firat University, Elazig 23119, Turkey.
} 
for different purposes, especially in the synthesis of heterocyclic substances [15].

In this paper, newly synthesized chloro-acetic acid $N^{\prime}--$ (2-hydroxy-naphthalen-1-ylmethylene)-N-[4-(3-methyl-3phenyl-cyclobutyl)-thiazol-2-yl]-hydrazide was characterized with the help of X-ray diffraction, FT-IR, NMR and UV-VIS spectroscopy. Also, these spectroscopic studies, molecular energy, net charge, Molecular Electrostatic Potential (MEP) and boundary orbitals of the title compound were carried out theoretically.

\section{Materials and methods}

\subsection{X-ray crystallography}

Diffraction data of the head crystal were collected using the STOE IPDS II (Imaging Plate Diffraction System) diffractometer. X-AREA and X-RED32 [16] programs were used for data collection and reduction processes, respectively. After the necessary corrections had been applied to the collected data, the title compound was solved by direct methods with the help of SHELXT-2015 [17] software and refined by the least squares method with the help of SHELXL-2015 [18] software included in the Olex2 [19] packet program. All non-hydrogen atom parameters were refined anisotropically and all $\mathrm{H}$ atom parameters were located geometrically and refined by using a riding model with $U_{\text {iso }}(H)=x U_{\text {eq }}$, where $\mathrm{x}=1.5$ for $\mathrm{CH}_{3}$ and $\mathrm{OH}$ groups and 1.2 for $\mathrm{CH}_{2}$ and $\mathrm{CH}$ groups. The $U_{\text {iso }}$ values for $\mathrm{H}$ atoms are in the range $0.063-0.236$.

\subsection{Synthesis}

The compound was synthesized as shown in Scheme 1 by the following procedure. To a stirred solution of 1-\{[4-(3-methyl-3-mesityl-cyclobutyl)-thiazol-2-yl]hydrazonomethyl\}-naphthalen-2-ol $(0.456 \mathrm{~g}, 1 \mathrm{mmol})$ in $30 \mathrm{~mL}$ of absolute ethanol, chloroacetyl chloride $(1 \mathrm{mmol})$ in $10 \mathrm{~mL}$ of absolute ethanol was added dropwise in $2 \mathrm{~h}$ period at room temperature in the presence of $1 \mathrm{mmol}$ triethylamine. After the mixture was stirred $2 \mathrm{~h}$ more and poured into water. Thus, precipitated solid substance was filtered off, washed with aqueous $\mathrm{NH}_{3}$ solution several times and dried in air. Suitable single crystals for crystal structure determination were obtained by slow evaporation of its ethanol solution. Yield: $67 \%$, melting point: $428 \mathrm{~K}$. Characteristic IR bands: $3390 \mathrm{~cm}^{-1}$ $\mathrm{v}(-\mathrm{OH}), 2957-2858 \mathrm{~cm}^{-1} \mathrm{v}$ (aliphatics), $1706 \mathrm{~cm}^{-1} \mathrm{v}(\mathrm{C}=\mathrm{O})$, $1623 \mathrm{~cm}^{-1} v(C=N$ azomethine $), 1593 \mathrm{~cm}^{-1} v(C=N$ thiazole), $736 \mathrm{v}(\mathrm{C}-\mathrm{Cl}), 639 \mathrm{~cm}^{-1} \mathrm{v}(\mathrm{C}-\mathrm{S}-\mathrm{C}$ thiazole). Characteristic ${ }^{1} \mathrm{H}$ NMR shifts $\left(\mathrm{CDCl}_{3}, \delta, \mathrm{ppm}\right): 1.60(\mathrm{~s}, 3 \mathrm{H}$, $-\mathrm{CH}_{3}$ in cyclobutane), $2.18\left(\mathrm{~s}, 6 \mathrm{H}, \mathrm{o}-\mathrm{CH}_{3}\right), 2.21(\mathrm{~s}, 3 \mathrm{H}$, p- $\left.\mathrm{CH}_{3}\right), 2.66-2.70\left(\mathrm{~m}, 4 \mathrm{H},-\mathrm{CH}_{2}-\right.$ in cyclobutane), 3.64 (q, $j=8.78 \mathrm{~Hz}, 1 \mathrm{H},>\mathrm{C}-\mathrm{H}$ in cyclobutane), $4.62\left(\mathrm{~s}, 2 \mathrm{H},-\mathrm{CH}_{2}-\mathrm{Cl}\right)$, $6.70(\mathrm{~s}, 2 \mathrm{H}$, aromatics $), 6.90(\mathrm{~d}, j=0.73 \mathrm{~Hz}, 1 \mathrm{H},=\mathrm{CH}-\mathrm{S}), 7.24$ $(\mathrm{t}, j=6.22 \mathrm{~Hz}, 2 \mathrm{H}$ aromatics), 7.38-7.46 (m, 2H, aromatics), 7.80-7.88 (m, $2 \mathrm{H}$, aromatics), $7.90(\mathrm{~d}, j=9.15 \mathrm{~Hz}, 1 \mathrm{H}$, aromatics), $9.82(\mathrm{~s}, 1 \mathrm{H}$, azomethine), $11.51(\mathrm{~s}, 1 \mathrm{H},-\mathrm{OH}$ $\mathrm{D}_{2} \mathrm{O}$ exchangeable). Characteristic ${ }^{13} \mathrm{C}$ NMR shifts $\left(\mathrm{CDCl}_{3}\right.$, $\delta, \mathrm{ppm}): 165.38,160.15,158.84,157.05,144.25,135.44$, 135.30, 134.88, 132.94, 130.57, 129.50, 128.57, 128.40, $124.21,119.92,119.23,111.90,107.61,43.97,42.79,41.23$, $31.71,24.78,21.65,20.65$.

\subsection{Computational details}

All theoretical calculations in the gas phase were performed by the Gaussian 09 program package [20] which use the density functional theory (DFT)/B3LYP [21-23] functional and the $6-31 \mathrm{G}(\mathrm{d})$ [24] basis set. GaussView 5 [25] program was used to visualize the obtained results. The solid phase calculations were performed using the Quantum Espresso software [26] within the density functional theory (DFT). The correlation functionals were performed by the generalized gradient approximation (GGA), as proposed by Perdew-Burke-Ernzerhof (PBE) [27] and Local Density Approach (LDA), as proposed by PerdewZunger (PZ) [28].

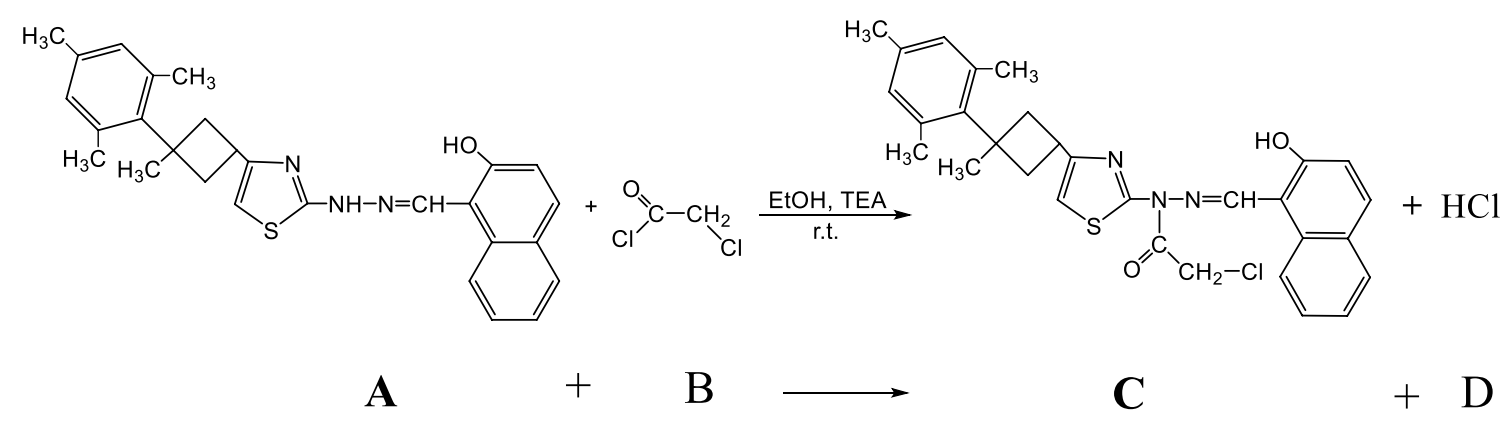

Scheme 1 Synthetic route for the synthesis of the target compound 


\section{Results and discussion}

\subsection{Geometrical structure}

The crystal parameters, data collection and details of refinement process are shown in Table 1 and a diagram, which the crystal drawn with experimental $20 \%$ probability ellipsoids, is shown in Fig. 1.

The molecule has non-coplanar thiazole, cyclobutane, trimethyl benzene and naphthalene rings. The angles between the cyclobutane-thiazole and the cyclobutanetrimethyl benzene rings are $55.09^{\circ}$ and $40.60^{\circ}$, respectively. Experimental and calculated bond lengths, bond angles and torsion angles are also shown in Table 3. The bond lengths of $\mathrm{O} 1-\mathrm{C} 1, \mathrm{C} 11=\mathrm{N} 1, \mathrm{C} 19-\mathrm{C} 17, \mathrm{~S} 1=\mathrm{C} 15$, C22-C20 and $\mathrm{C} 14=\mathrm{N} 3$ are experimentally 1.351 (3), 1.279 (3), 1.527 (4), 1.704 (2), 1.522 (4) and 1.303 (3) $\AA$, respectively and these lengths are in accordance with the literature values $[29,30]$. The crystal has $\mathrm{C}-\mathrm{H} \ldots \mathrm{O}$ intermolecular and $\mathrm{O}-\mathrm{H} \ldots \mathrm{N}$ and $\mathrm{C}-\mathrm{H} \ldots \mathrm{N}$ intramolecular

Table 1 Data collection and refinement values of title compound

\begin{tabular}{|c|c|}
\hline Empirical formula & $\mathrm{C}_{30} \mathrm{H}_{30} \mathrm{ClN}_{3} \mathrm{O}_{2} \mathrm{~S}$ \\
\hline Formula weight & 532.08 \\
\hline Temperature/K & $293(2)$ \\
\hline Crystal system & Monoclinic \\
\hline Space group & $\mathrm{P} 2{ }_{1} / \mathrm{c}$ \\
\hline $\mathrm{a} / \AA ̊$ & $16.4126(9)$ \\
\hline $\mathrm{b} / \AA ̊$ & $23.5804(9)$ \\
\hline$c / \AA$ & $7.1367(4)$ \\
\hline$a /^{\circ}$ & 90 \\
\hline$\beta /^{\circ}$ & $96.558(4)$ \\
\hline$\gamma /{ }^{\circ}$ & 90 \\
\hline Volume $/ \AA^{3}$ & $2743.9(2)$ \\
\hline Z & 4 \\
\hline$\rho_{\text {calc }} g / \mathrm{cm}^{3}$ & 1.288 \\
\hline$\mu / \mathrm{mm}^{-1}$ & 0.247 \\
\hline$F(000)$ & 1120.0 \\
\hline Crystal size $/ \mathrm{mm}^{3}$ & $0.50 \times 0.28 \times 0.14$ \\
\hline Radiation & MoKa $(\lambda=0.71073)$ \\
\hline $2 \Theta$ range for data collection $/{ }^{\circ}$ & 2.498 to 53.574 \\
\hline Index ranges & $-20 \leq h \leq 20,-29 \leq k \leq 29,-9 \leq \mathrm{I} \leq 8$ \\
\hline Reflections collected & 28,334 \\
\hline Independent reflections & $5816\left[R_{\text {int }}=0.0683, R_{\text {sigma }}=0.0514\right]$ \\
\hline Data/restraints/parameters & $5816 / 0 / 339$ \\
\hline Goodness-of-fit on $\mathrm{F}^{2}$ & 0.961 \\
\hline Final $R$ indexes $[I>=2 \sigma(I)]$ & $\mathrm{R}_{1}=0.0505, \mathrm{wR}_{2}=0.1088$ \\
\hline Final $R$ indexes [all data] & $\mathrm{R}_{1}=0.1000, \mathrm{wR}_{2}=0.1257$ \\
\hline Largest diff. peak/hole/e $\AA^{-3}$ & $0.27 /-0.28$ \\
\hline CCDC & 761,391 \\
\hline
\end{tabular}

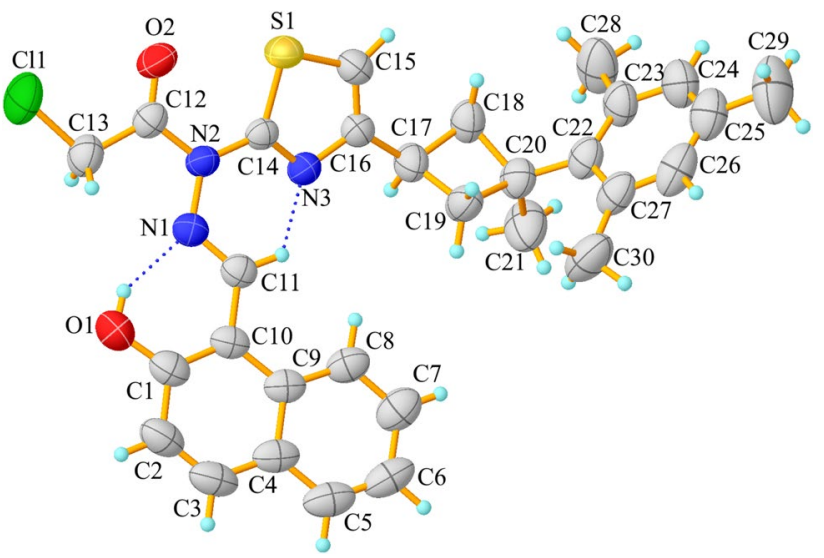

Fig. 1 ORTEP-3 shape of the title compound

hydrogen bonds. The crystal is also stabilized by normal van der Waal's forces and by $\pi-\pi$ stacking interactions between the naphthalene rings. The molecular structure has adopted the enol-imine form and has been stabilized by the $\mathrm{O}-\mathrm{H} \ldots \mathrm{N}$ type intramolecular hydrogen bonding. The bond lengths $\mathrm{C} 1-\mathrm{O} 1$ showing the single bond character and $\mathrm{C} 11=\mathrm{N} 1$ showing the double bond character support that the molecule adopts the enol-imine form. These bond lengths agree with the bond lengths obtained from similar enol-imine form structures [31, 32]. It is observed that $\mathrm{C}-\mathrm{H} \ldots \mathrm{.}$.O hydrogen bond between linking adjacent molecules formed a chain sequence along the b-axis direction with graph set analysis $C(10)$ motif (Fig. 2) and $\mathrm{N}-\mathrm{H} \ldots \mathrm{O}$ hydrogen bond generates an $S(6)$ ring motif.

In addition, within the title compound, there is a $\pi \cdots \pi$ interactions occur between the naphthalene rings of neighboring molecules linked by symmetry. The centroid-centroid distance between $\mathrm{Cg} 1$ (C4-C9) and $\mathrm{Cg} 2^{\mathrm{ii}}$ (C3/C4/C9/C1/C2/C10) [symmetry code: $1-\mathrm{x},-1 / 2+\mathrm{y}$, $1 / 2-z]$ is $3.959(2) \AA$. As a result of the structure solution and refinement, ORTEP- 3 of the obtained structure and the packaging drawing of the title compound in the unit cell are shown in Figs. 2 and 3, and the information about the hydrogen bindings are shown in Table 2 .

In order that the stable molecular structure may be found, the global minimum scanning (2-dimensional PES analysis) were realized on the potential energy surfaces using AM1 semiempirical method [33]. Single point energies were calculated, which can affect the lowest energy conformation belonging to the molecule, changing the torsion angle $\theta$ (N1-N2-C14-S1) in steps of $10^{\circ}$ ranging from $-180^{\circ}$ to $180^{\circ}$. The two-dimensional single point energy profile versus the torsion angle is shown in Fig. 4. With the help of this graphic, global and local minimums were determined. 
Fig. 2 Representation of intermolecular hydrogen bonds of the title compound. Hydrogens that do not contribute to binding have been deleted for clear indication

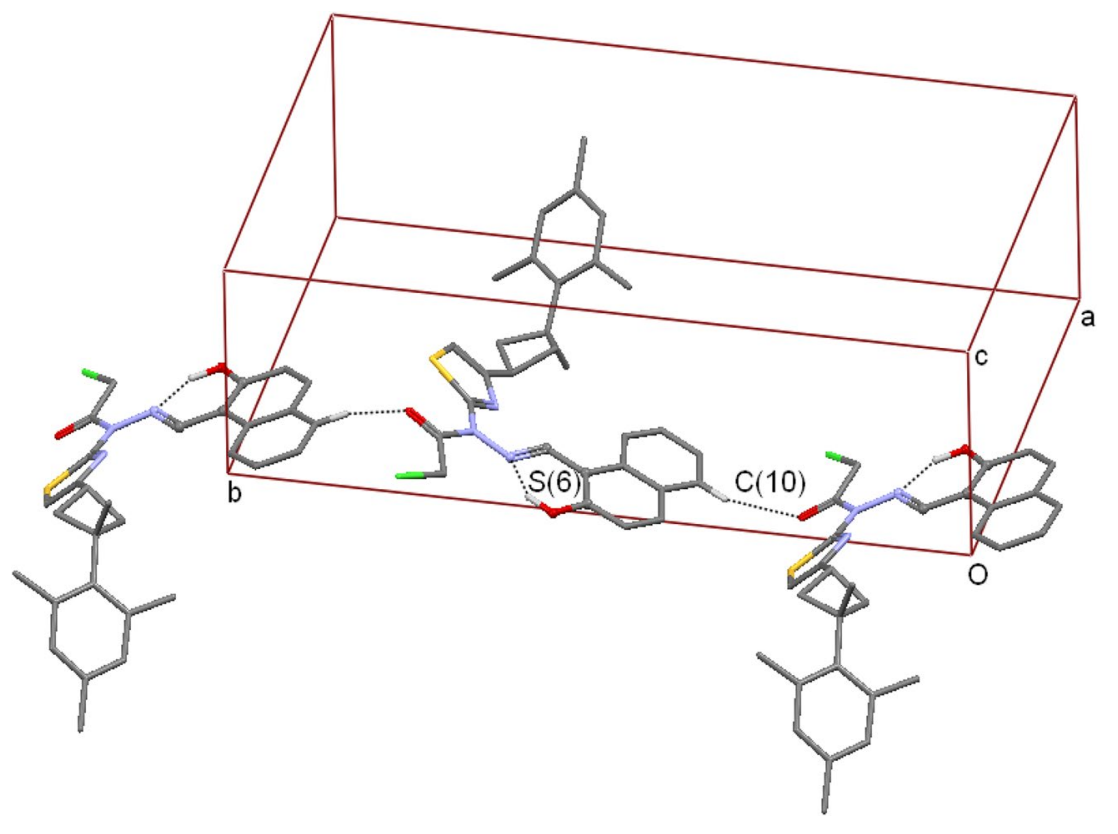

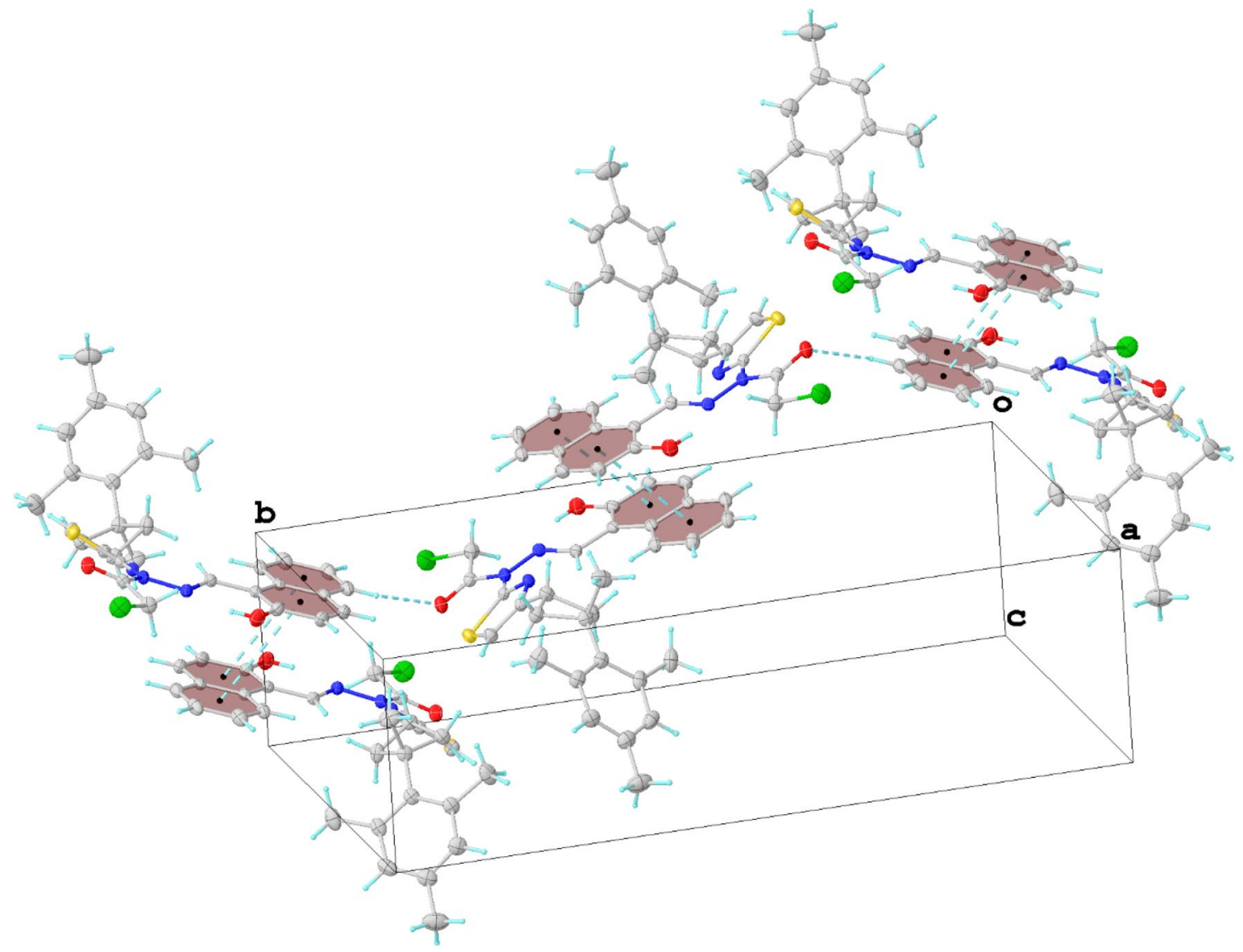

Fig. 3 Packing of the title compound with $\mathrm{C}-\mathrm{H} \cdots \mathrm{O}$ and $\pi-\pi$ interactions along the $\mathrm{c}$ axis 
Table 2 Hydrogen bond geometry for the title single compound

\begin{tabular}{lllll}
\hline $\mathrm{D}-\mathrm{H} \cdots \mathrm{A}$ & $\mathrm{D}-\mathrm{H}(\AA \AA)$ & $\mathrm{H} \cdots \mathrm{A}(\AA)$ & $\mathrm{D} \cdots \mathrm{A}(\AA \AA)$ & $\mathrm{D}-\mathrm{H} \cdots \mathrm{A}\left({ }^{\circ}\right)$ \\
\hline $\mathrm{C} 5-\mathrm{H} 5 \cdots \mathrm{O} 2^{\mathrm{i}}$ & 0.930 & 2.130 & $2.767(3)$ & 125 \\
$\mathrm{O} 1-\mathrm{H} 1 \cdots \mathrm{N} 1$ & 0.820 & 1.930 & $2.643(3)$ & 146 \\
$\mathrm{C} 11-11 \cdots \mathrm{N} 3$ & 0.930 & 2.130 & $2.769(3)$ & 125 \\
$\mathrm{Cg}(\mathrm{I})$ & $\mathrm{Cg}(\mathrm{J})$ & $\mathrm{Cg} \cdots \mathrm{Cg}(\AA)$ & & \\
$\mathrm{Cg} 1$ & $\mathrm{Cg} 2^{\mathrm{ii}}$ & 3.959 & & \\
\hline
\end{tabular}

Symmetry codes (i): $-x,+y-1 / 2,-z+1 / 2$, (ii): $-x, 1-y, z$

$\mathrm{Cg} 1$ the centroid of the (C4-C9) ring; $\mathrm{Cg} 2$ the centroid of the (C3$\mathrm{C} 4 / \mathrm{C} 9 / \mathrm{C} 1-\mathrm{C} 2 / \mathrm{C} 10)$ ring

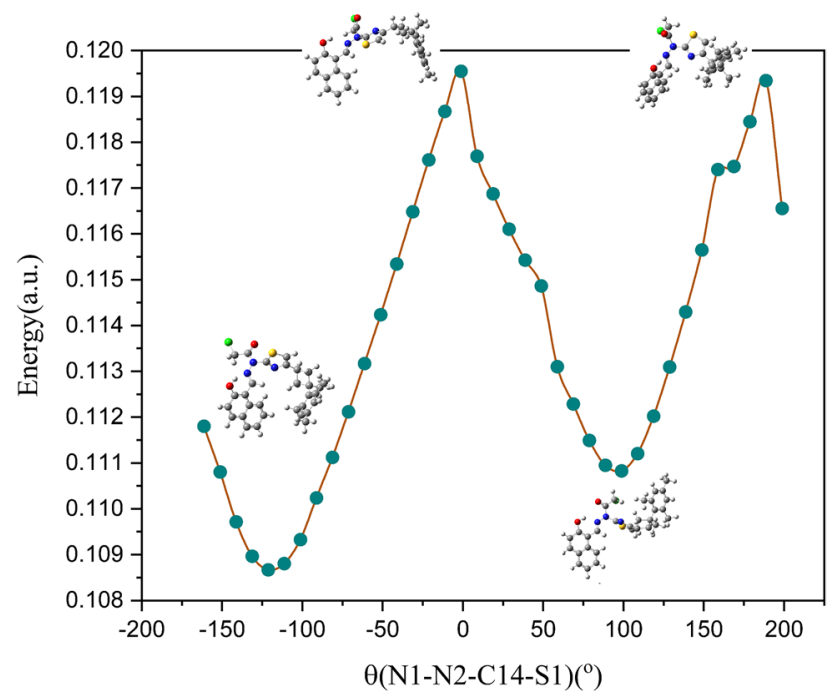

Fig. 4 Molecular energy profile versus the selected torsional degree of freedom

As seen in Fig. 4, the two most stable conformer (conf1 and conf2) were identified corresponding to global and local values at nearly $-120^{\circ}$ and $100^{\circ}$ angles. As a result of the re-optimization of the obtained two conformer, the corresponding total energy values were determined as -2334.315800 a.u. (conf1) (Fig. 5a) and - 2334.310532 a.u. (conf2) (Fig. 5b). The conf1 conformation, which has a lower total energy, is more stable and has been used in all theoretical calculations.

Experimental and theoretical bond lengths, bond angles and torsional angles in the gas and solid phases of the title compound are listed comparatively in Table 3. When the calculated values in the Table 3 are examined, it is seen that HF method for bond lengths and B3LYP method for bond angles are more successful in representing experimental geometry in gas phase. Likewise, the GGA method has yielded better results than the LDA method for all parameters in the solid phase.

Figure 6 shows the overlap of X-ray and calculated molecular geometries. The RMS values resulting from the superposition of the experimental and theoretically structures were found to be $0.631 \AA$ for HF level and $0.470 \AA$ for B3LYP level. According to these results, DFT method has less error and characterizes the three dimensional structure of molecular geometry better than HF method.

\subsection{Periodic boundary calculations (PBC)}

The coordinates of 268 atoms in the unit cell were obtained from the cif file of the title compound and the kinetic energy cut-off (Ecut) value to model the system in the Plane Wave Self-Compliance field program was selected as 80 Ry. Furthermore, lattice constant was taken as 31.0155 a.u. and the numbers of k-point mesh for the Brillouin region were determined by MP (Monkhorst-Pack) method [34] and taken as $2 \times 2 \times 2$. In order to increase the accuracy of the results of the total energy calculation, a convergence value of $10^{-6}$ Rydberg (Ry) was used. The optimized parameters of the unit cell were obtained using

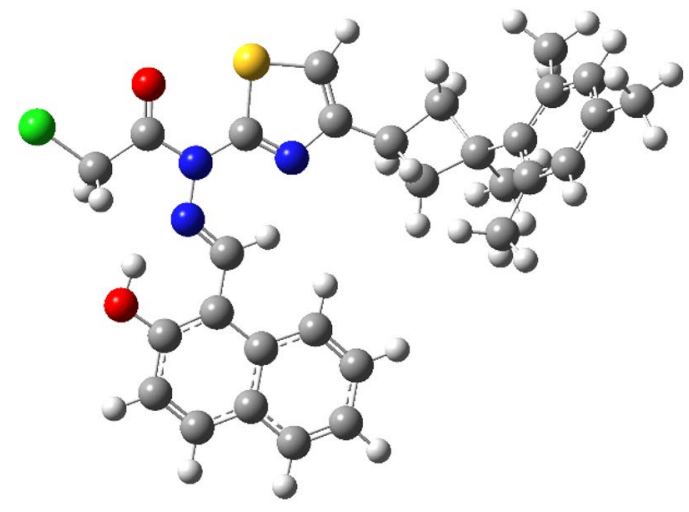

(a)

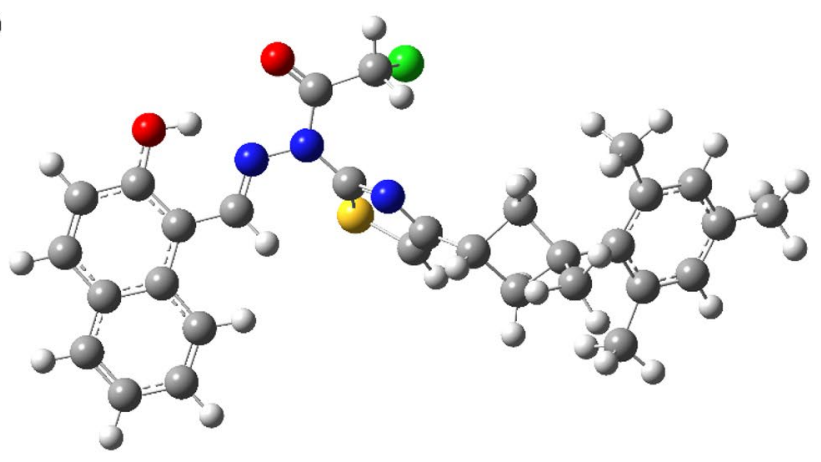

(b)

Fig. 5 Optimized conformations of the title compound crystal; a conf1, b conf2 
Table 3 Some experimental and theoretically obtained geometric parameters

\begin{tabular}{|c|c|c|c|c|c|}
\hline & X-ray & $\mathrm{HF}$ & DFT & LDA & GGA \\
\hline \multicolumn{6}{|l|}{ Bond lengths $(\AA ̊)$} \\
\hline $\mathrm{O} 1-\mathrm{C} 1$ & $1.351(3)$ & 1.324 & 1.345 & 1.325 & 1.350 \\
\hline $\mathrm{O} 2-\mathrm{C} 12$ & $1.205(3)$ & 1.189 & 1.215 & 1.219 & 1.226 \\
\hline $\mathrm{N} 2-\mathrm{C} 14$ & $1.406(3)$ & 1.402 & 1.414 & 1.390 & 1.415 \\
\hline $\mathrm{C} 14-\mathrm{N} 3$ & $1.303(3)$ & 1.275 & 1.304 & 1.302 & 1.311 \\
\hline $\mathrm{C} 11-\mathrm{N} 1$ & $1.279(3)$ & 1.27 & 1.301 & 1.294 & 1.307 \\
\hline C12-N2 & $1.389(3)$ & 1.379 & 1.404 & 1.377 & 1.403 \\
\hline $\mathrm{S} 1-\mathrm{C} 15$ & $1.704(2)$ & 1.735 & 1.738 & 1.702 & 1.723 \\
\hline $\mathrm{S} 1-\mathrm{C} 14$ & $1.723(2)$ & 1.739 & 1.768 & 1.721 & 1.752 \\
\hline N3-C16 & $1.379(3)$ & 1.385 & 1.384 & 1.359 & 1.378 \\
\hline $\mathrm{C} 17-\mathrm{C} 18$ & $1.529(3)$ & 1.535 & 1.543 & 1.537 & 1.553 \\
\hline C19-C17 & $1.527(4)$ & 1.540 & 1.552 & 1.521 & 1.543 \\
\hline $\mathrm{C} 20-\mathrm{C} 18$ & $1.557(4)$ & 1.563 & 1.574 & 1.554 & 1.575 \\
\hline $\mathrm{C} 20-\mathrm{C} 21$ & $1.544(4)$ & 1.538 & 1.543 & 1.512 & 1.537 \\
\hline $\mathrm{C} 22-\mathrm{C} 20$ & $1.522(4)$ & 1.536 & 1.534 & 1.504 & 1.530 \\
\hline RMS & & 0.010 & 0.012 & 0.015 & 0.012 \\
\hline \multicolumn{6}{|l|}{ Bond angles $\left({ }^{\circ}\right)$} \\
\hline $\mathrm{C} 11-\mathrm{N} 1-\mathrm{N} 2$ & $120.0(2)$ & 124.93 & 123.27 & 120.08 & 120.81 \\
\hline $\mathrm{N} 2-\mathrm{C} 12-\mathrm{C} 13$ & $115.0(2)$ & 114.27 & 115.71 & 115.20 & 115.46 \\
\hline $\mathrm{O} 1-\mathrm{C} 1-\mathrm{C} 10$ & $122.9(2)$ & 124.35 & 122.58 & 121.26 & 121.41 \\
\hline $\mathrm{C} 12-\mathrm{N} 2-\mathrm{N} 1$ & $115.1(2)$ & 116.94 & 114.03 & 116.38 & 115.18 \\
\hline $\mathrm{C} 12-\mathrm{N} 2-\mathrm{C} 14$ & $120.5(2)$ & 122.36 & 119.73 & 119.11 & 119.36 \\
\hline $\mathrm{N} 1-\mathrm{N} 2-\mathrm{C} 14$ & $124.5(2)$ & 122.85 & 126.22 & 124.49 & 125.44 \\
\hline $\mathrm{C} 17-\mathrm{C} 18-\mathrm{C} 20$ & $90.1(2)$ & 89.67 & 89.74 & 89.705 & 90.51 \\
\hline C19-C17-C18 & $87.6(2)$ & 88.01 & 88.01 & 88.400 & 88.40 \\
\hline $\mathrm{C} 22-\mathrm{C} 20-\mathrm{C} 18$ & $117.1(2)$ & 117.98 & 118.14 & 116.84 & 116.14 \\
\hline$C 24-C 23-C 22$ & $119.6(3)$ & 120.09 & 119.87 & 119.74 & 119.75 \\
\hline$C 25-C 24-C 23$ & $123.4(3)$ & 122.37 & 122.50 & 122.32 & 122.66 \\
\hline RMS & & 1.896 & 1.346 & 0.860 & 0.841 \\
\hline \multicolumn{6}{|l|}{ Dihedral angles $\left(^{\circ}\right)$} \\
\hline $\mathrm{N} 1-\mathrm{N} 2-\mathrm{C} 14-\mathrm{S} 1$ & $-161.16(15)$ & -165.62 & -175.55 & -162.10 & -170.34 \\
\hline $\mathrm{C} 12-\mathrm{N} 2-\mathrm{N} 1-\mathrm{C} 11$ & $-164.89(19)$ & 129.60 & 178.40 & -167.94 & -162.99 \\
\hline $\mathrm{C} 15-\mathrm{S} 1-\mathrm{C} 14-\mathrm{N} 3$ & $-0.4(2)$ & -0.59 & -0.47 & -0.00 & 0.19 \\
\hline N3-C16-C17-C18 & $172.6(2)$ & -171.81 & -171.54 & 174.23 & 179.78 \\
\hline $\mathrm{C} 23-\mathrm{C} 22-\mathrm{C} 20-\mathrm{C} 19$ & $-143.46(18)$ & -142.35 & -142.46 & -143.08 & -145.86 \\
\hline $\mathrm{C} 23-\mathrm{C} 22-\mathrm{C} 20-\mathrm{C} 21$ & $85.9(3)$ & 89.40 & 88.32 & 88.00 & 85.04 \\
\hline
\end{tabular}

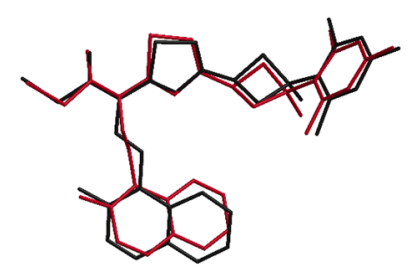

HF

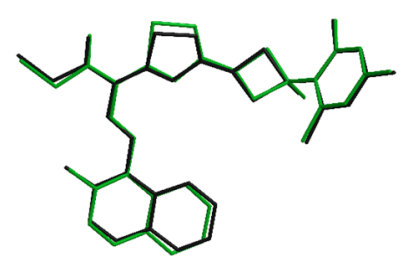

DFT

Fig. 6 The overlapping of the geometry (black) obtained from the $\mathrm{X}$-ray diffraction of the crystal and the optimized geometries determined using HF and DFT methods

Table 4 Comparison of the experimental and optimized unit-cell parameters calculated by the Quantum ESPRESSO (QE) VC-Relax method

\begin{tabular}{llll}
\hline $\begin{array}{l}\text { Unit cell } \\
\text { parameters }\end{array}$ & $\begin{array}{l}\text { Experimental } \\
\text { X-ray }\end{array}$ & $\begin{array}{l}\text { GGA } \\
\text { PBE }\end{array}$ & $\begin{array}{l}\text { LDA } \\
\text { PZ }\end{array}$ \\
\hline$a(\AA)$ & $16.4126(9)$ & 16.60550 & 15.79458 \\
$b(\AA)$ & $23.5804(9)$ & 24.30976 & 22.88768 \\
$c(\AA)$ & $7.1367(4)$ & 8.19235 & 6.70280 \\
$\beta\left(\left(^{\circ}\right)\right.$ & $96.558(4)$ & 99.5814 & $96.5681^{\circ}$ \\
$Z$ & 4 & 4 & 4 \\
$V\left(\AA^{3}\right)$ & $2743.9(2)$ & 3260.9193 & 2407.1674 \\
\hline
\end{tabular}


QE-VC-Relax method and BFGS (Broyden-Fletcher-Goldfarb-Shanno) quasi-Newton optimization algorithm. Table 4 shows the unit cell parameters obtained from $X$-ray and calculated using GGA and LDA methods while Fig. $7 a-c$ is shown the distribution of atoms within the unit cell. In addition, the total lattice energy values per unit cell were obtained using the scf (self-consistent field) set included in Quantum-Espresso packet program for GGA and LDA methods. The energy values according to GGA and LDA methods were found to be -2208.76400880 Ry and -2201.94258365 Ry, respectively, which indicate that the GGA method has reached a more stable structure than the LDA method.

\subsection{Spectroscopic studies}

The experimental and calculated IR spectra of the title compound is shown in Fig. 8 and vibration frequency values are given in Table 5. The molecule has 195 normal modes of vibration. The essential characteristic vibrations of the title compound are $\mathrm{C}-\mathrm{H}$ (aromatic), $\mathrm{C}=\mathrm{O}, \mathrm{C}=\mathrm{N}$ (thiazole) and $\mathrm{N}-\mathrm{C}=\mathrm{S}$ vibrational frequencies connected to the ring groups were experimentally observed to be $3098,1706,1593$ and $1207 \mathrm{~cm}^{-1}$, respectively, as compatible with the literature $[35,36]$. These modes have been calculated at $3083,1781,1476$ and $1192 \mathrm{~cm}^{-1}$ for HF level and at $3148,1726,1472$ and $1217 \mathrm{~cm}^{-1}$ for B3LYP level. While the $\mathrm{O}-\mathrm{H}$ group, which does not contain an intramolecular or intermolecular hydrogen bonding, has a free vibration frequency between 3700 and $3550 \mathrm{~cm}^{-1}$, this vibration frequency containing hydrogen bonding is observed between 3550 and $3200 \mathrm{~cm}^{-1}$ [37]. In our study, this frequency value was observed at $3293 \mathrm{~cm}^{-1}$, while it

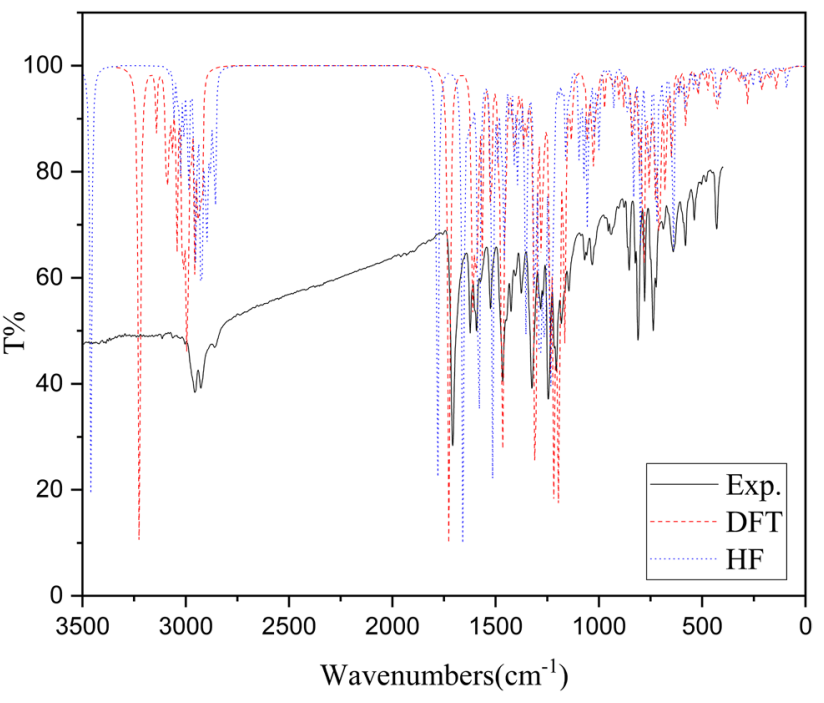

Fig. 8 Experimental and calculated IR spectra

was calculated at $3459 \mathrm{~cm}^{-1}$ for HF level and at $3224 \mathrm{~cm}^{-1}$ for B3LYP level and compares well with the value reported previously as $3436 \mathrm{~cm}^{-1}$ for experimentally and $3406 \mathrm{~cm}^{-1}$ for B3LYP level [38].

Experimental and calculated ${ }^{1} \mathrm{H}$ and ${ }^{13} \mathrm{C}$ chemical shift values for the title molecule are given comparatively in Table 6. The peaks of the $\mathrm{C} 14, \mathrm{C} 15$ and $\mathrm{C} 16$ atoms in the ${ }^{13} \mathrm{C}$-NMR spectrum (Fig. 9) may indicate that the molecule has a thiazole ring. The chemical shift values of these atoms are higher than other carbon atoms. Due to deshielding by the electronegative property of the $\mathrm{N}$ and $S$ atoms, the chemical shift values of C14, C15 and $\mathrm{C} 16$ atoms are greater than the other carbon atoms and

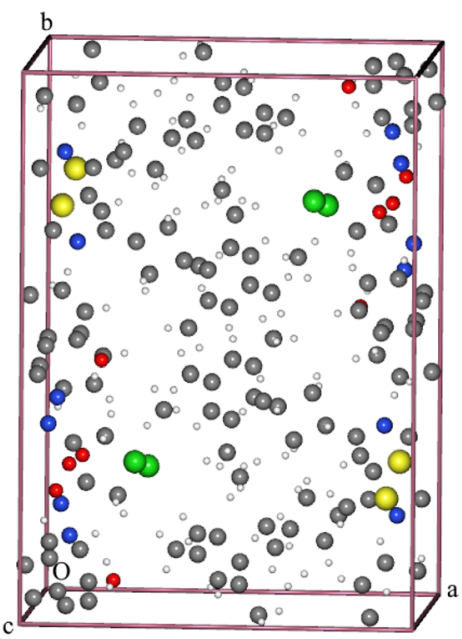

(a)

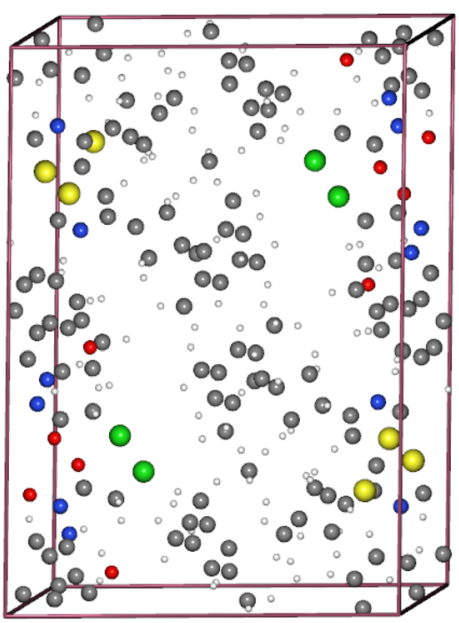

(b)

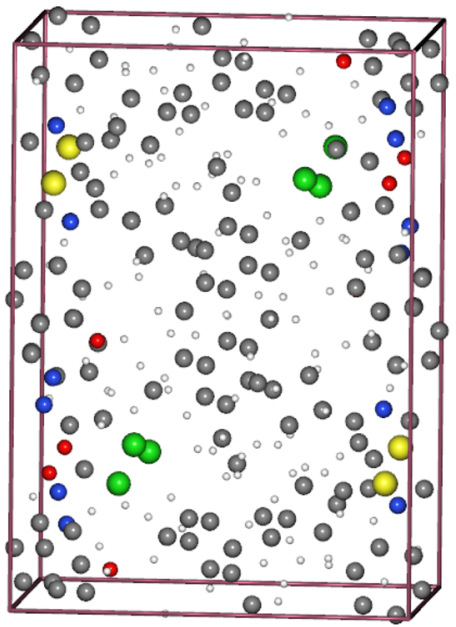

(c)

Fig. 7 Representation of atoms within the unit cell of the title compound a X-ray, b QE-VC-relax; GGA, c QE-VC-Relax; LDA 
Table 5 Comparison of the experimental and calculated vibrational spectra

\begin{tabular}{|c|c|c|c|}
\hline \multirow[t]{2}{*}{ Assignments } & \multirow[t]{2}{*}{ FT-IR $\left(\mathrm{cm}^{-1}\right)$} & \multicolumn{2}{|c|}{$\begin{array}{l}\text { Scaled frequen- } \\
\text { cies }(6-31 G(d)) \\
\left(\mathrm{cm}^{-1}\right)\end{array}$} \\
\hline & & $\mathrm{HF}$ & DFT \\
\hline$v \mathrm{O}-\mathrm{H}$ & 3293 & 3459 & 3224 \\
\hline$v$ ring $\mathrm{C}-\mathrm{H}$ & 3098 & 3083 & 3148 \\
\hline$v$ aliphatic $\mathrm{C}-\mathrm{H}$ & 2957 & 3058 & 3141 \\
\hline$v$ aliphatic $\mathrm{C}-\mathrm{H}$ & 2928 & - & - \\
\hline$v C=O$ & 1706 & 1781 & 1726 \\
\hline$v$ azometine $\mathrm{C}=\mathrm{N}$ & 1623 & 1583 & 1565 \\
\hline$v$ thiazole $\mathrm{C}=\mathrm{N}$ & 1593 & 1476 & 1472 \\
\hline$v$ aromatic $\mathrm{C}-\mathrm{C}$ & 1572 & 1631 & 1602 \\
\hline$v$ thiazole $\mathrm{C}=\mathrm{C}$ & 1525 & 1622 & 1599 \\
\hline$\rho_{s} \mathrm{CH}_{2}$ & 1465 & 1573 & 1523 \\
\hline$\rho_{t}$ aromatic $\mathrm{C}-\mathrm{H}$ & 1425 & 1466 & 1465 \\
\hline$\rho_{w} \mathrm{CH}_{3}$ & 1376 & 1430 & 1426 \\
\hline$v \mathrm{C}-\mathrm{N}$ & 1324 & 1396 & 1386 \\
\hline$\rho_{t} \mathrm{C}-\mathrm{H}+\mathrm{C}-\mathrm{CH}$ & 1282 & 1287 & 1328 \\
\hline$v \mathrm{C}-\mathrm{N}+\rho_{w} \mathrm{CH}_{2}$ & 1245 & 1230 & 1279 \\
\hline$v \mathrm{~N}-\mathrm{C}=\mathrm{S}$ & 1207 & 1192 & 1217 \\
\hline$\rho_{t}$ aromatic $\mathrm{C}-\mathrm{H}$ & 1182 & 1179 & 1193 \\
\hline$\rho_{t}$ aromatic $\mathrm{C}-\mathrm{H}$ & 1145 & 1142 & 1188 \\
\hline$\rho_{t} \mathrm{~N}-\mathrm{H}+\rho_{t} \mathrm{C}-\mathrm{H}+v \mathrm{C}-\mathrm{N}$ & 1099 & 1132 & 1074 \\
\hline$\rho_{t} \mathrm{C}-\mathrm{H}$ & 1069 & 1074 & 1077 \\
\hline$\rho_{w} \mathrm{CH}_{3}$ & 1032 & 1055 & 1034 \\
\hline$\rho_{w} \mathrm{CH}$ & 954 & 973 & 947 \\
\hline$v \mathrm{C}-\mathrm{H}$ & 853 & 867 & 856 \\
\hline$\gamma \mathrm{C}-\mathrm{H}$ & 812 & 866 & 845 \\
\hline$v \mathrm{C}-\mathrm{Cl}$ & 778 & 799 & 784 \\
\hline$\gamma \mathrm{C}-\mathrm{H}$ & 736 & 756 & 731 \\
\hline$\gamma \mathrm{C}-\mathrm{H}$ & 638 & 641 & 647 \\
\hline
\end{tabular}

$v$ stretching; $\rho_{\mathrm{s}}$ makaslama; $\rho_{\mathrm{t}}$ rocking; $\rho_{\mathrm{w}}$ wagging; $\gamma$ out of plane bending

were experimentally found to be $165.38,107.61$ and $153.3 \mathrm{ppm}$, respectively which is consistent with the values reported previously (168.54, 99.58 and $151.07 \mathrm{ppm})$ [38]. Similarly, the $C 1$ and $C 12$ carbon peaks linked to 01 and $\mathrm{O} 2$ atoms were experimentally found to be 157.05 and $160.15 \mathrm{ppm}$. These values agree with similar molecules [39]. The $\mathrm{C} 1, \mathrm{C} 12, \mathrm{C} 14, \mathrm{C} 15$ and $\mathrm{C} 16$ peaks were calculated at 162.95, 174.60, 173.11, 109.32 and 151.23 ppm for HF theory, respectively and at 153.3, 159.31, 155.56, 109.34 and $146.55 \mathrm{ppm}$ for DFT theory.

In the ${ }^{1} \mathrm{H}$-NMR spectrum (Fig. 10), the hydroxy hydrogen peak in the naphthalene ring was experimentally observed as a single proton peak at $11.51 \mathrm{ppm}$ due to the formation of $\mathrm{O}-\mathrm{H}$... N intramolecular hydrogen bonding.
Table 6 Experimental and calculated NMR spectra

\begin{tabular}{|c|c|c|c|}
\hline Atoms & $\begin{array}{l}\text { Experimental } \\
(\mathrm{ppm})\left(\mathrm{CDCl}_{3}\right)\end{array}$ & $\begin{array}{l}\mathrm{HF} 6-31 \mathrm{G}(\mathrm{d}) \\
\left.(\mathrm{ppm})(\mathrm{CDCl})_{3}\right)\end{array}$ & $\begin{array}{l}\text { B3LYP } \\
6-31 G(d) \\
(p p m)\left(C D C l_{3}\right)\end{array}$ \\
\hline C1 & 157.05 & 162.95 & 153.3 \\
\hline$C 2$ & 119.23 & 114.58 & 112.13 \\
\hline C3 & 132.94 & 141.11 & 129.76 \\
\hline C4 & 130.57 & 124.27 & 121.22 \\
\hline $\mathrm{C} 5$ & 129.50 & 131.44 & 123.74 \\
\hline C6 & 119.92 & 121.02 & 117.09 \\
\hline$C 7$ & 128.40 & 130.94 & 121.83 \\
\hline C8 & 124.21 & 117.94 & 114.1 \\
\hline C9 & 135.44 & 136.96 & 127.55 \\
\hline C10 & 111.90 & 101.41 & 104.2 \\
\hline C11 & 158.84 & 162.48 & 145.99 \\
\hline C12 & 160.15 & 174.60 & 159.31 \\
\hline C13 & 43.97 & 46.58 & 50.63 \\
\hline C14 & 165.38 & 173.11 & 155.56 \\
\hline C15 & 107.61 & 109.32 & 109.34 \\
\hline C16 & 153.3 & 151.23 & 146.55 \\
\hline C17 & 31.71 & 28.41 & 32.38 \\
\hline C18 & 42.79 & 35.56 & 39.84 \\
\hline C19 & 42.79 & 39.45 & 44.04 \\
\hline C20 & 24.78 & 35.64 & 44.09 \\
\hline C21 & 41.23 & 23.73 & 24.08 \\
\hline C22 & 144.25 & 142.62 & 138.1 \\
\hline C23 & 134.88 & 136.18 & 129.56 \\
\hline C24 & 128.57 & 128.67 & 124.09 \\
\hline C25 & 135.3 & 134.85 & 128.23 \\
\hline C26 & 128.57 & 128.57 & 124.05 \\
\hline C27 & 134.88 & 136.17 & 129.79 \\
\hline C28 & 20.65 & 21.56 & 22.57 \\
\hline C29 & 21.65 & 19.81 & 20.94 \\
\hline C30 & 20.65 & 21.34 & 22.78 \\
\hline $\mathrm{H}(\mathrm{OH})$ & 11.51 & 10.85 & 10.04 \\
\hline $\mathrm{H}\left(\mathrm{CH}_{3}\right.$ cyclobutane $)$ & 1.60 & $1.60-1.92$ & $1.56-1.93$ \\
\hline $\mathrm{H}\left(\mathrm{o}-\mathrm{CH}_{3}\right)$ & 2.18 & $2.17-2.40$ & $1.97-2.32$ \\
\hline $\mathrm{H}\left(p-\mathrm{CH}_{3}\right)$ & 2.21 & $1.97-2.61$ & $1.76-2.55$ \\
\hline $\begin{array}{l}\mathrm{H}\left(-\mathrm{CH}_{2} \text { cyclobu- }\right. \\
\text { tane) }\end{array}$ & $2.66-2.70$ & $2.40-3.00$ & $2.50-2.99$ \\
\hline $\begin{array}{l}\mathrm{H}(\mathrm{C}-\mathrm{H} \text { cyclobu- } \\
\quad \text { tane) }\end{array}$ & 3.64 & 3.59 & 3.86 \\
\hline $\mathrm{H}\left(-\mathrm{CH}_{2}-\mathrm{Cl}\right)$ & 4.62 & $4.54-4.62$ & $4.66-4.75$ \\
\hline $\mathrm{H}$ (aromatic) & $6.70-7.89$ & $7.01-8.54$ & $6.66-8.64$ \\
\hline $\mathrm{H}(\mathrm{N}=\mathrm{CH})$ & 9.82 & 12.50 & 11.74 \\
\hline $\mathrm{H}(=\mathrm{CH}-\mathrm{S})$ & 6.90 & 5.43 & 6.28 \\
\hline
\end{tabular}

In theoretical calculations, it was found that this peak was close to the experimental results at $10.85 \mathrm{ppm}$ for $\mathrm{HF}$ and at $10.04 \mathrm{ppm}$ for DFT. 
Fig. $9{ }^{13} \mathrm{C}$ NMR spectrum of target compound

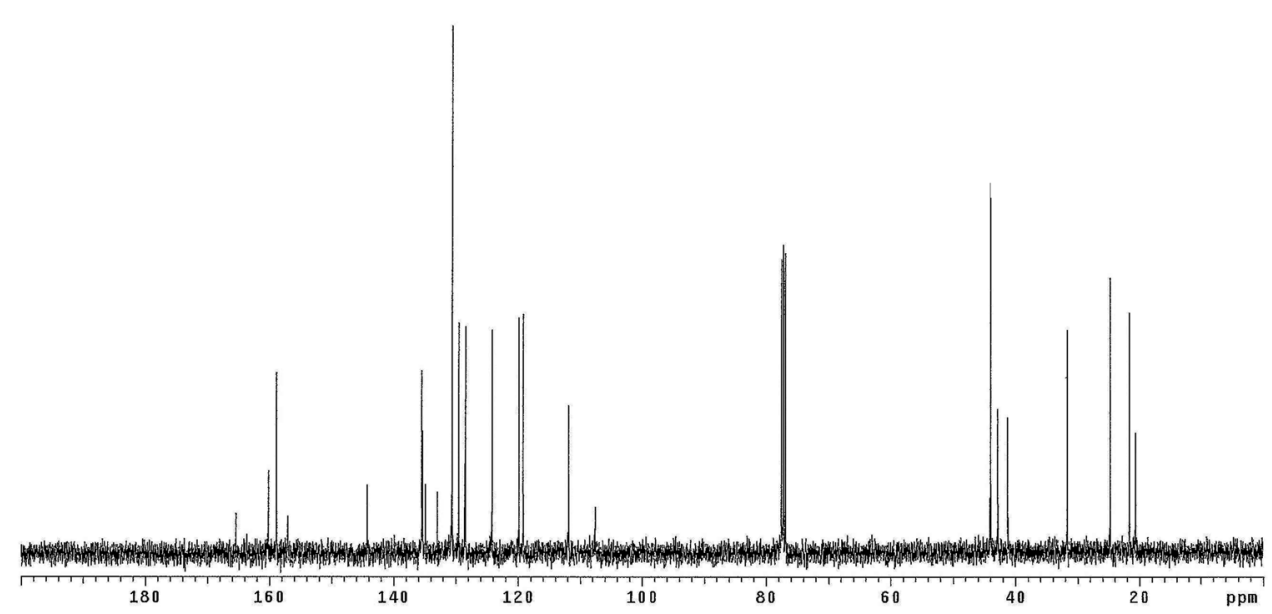

Fig. $10{ }^{1} \mathrm{H}$ NMR spectrum of target compound

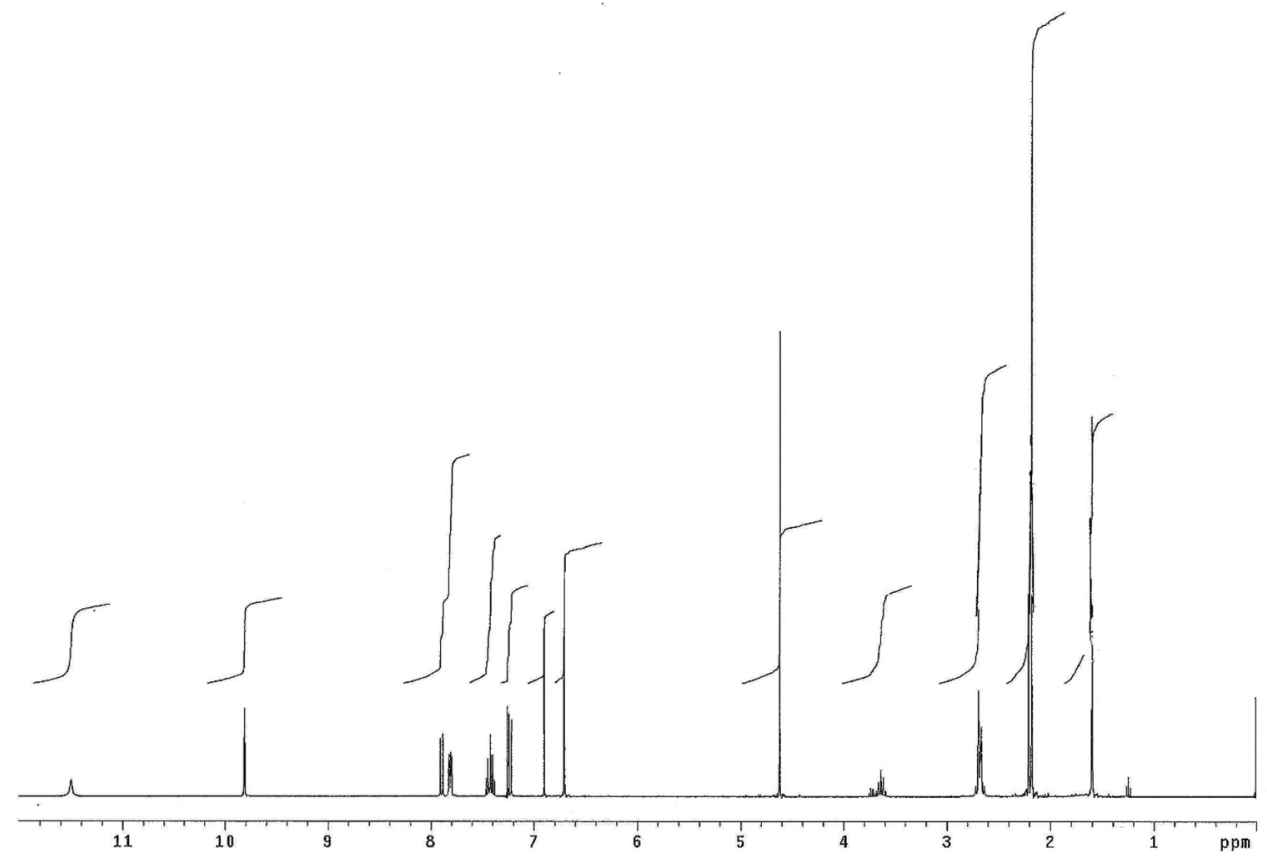

\subsection{Total charge distribution, electronic properties and MEPs of the title compound}

Mulliken, ESP, NPA and Hirshfeld charge distributions of the title compound were calculated using the DFT/ B3LYP/6-31G(d) method and are shown in Table 7. When the charge distributions are examined, it is seen that the most negative charges are collected on $\mathrm{N}, \mathrm{O}$ and $\mathrm{Cl}$ atoms while the most positive charges are on $\mathrm{C} 11, \mathrm{C} 12, \mathrm{C} 14$, $\mathrm{C} 16$ and $\mathrm{H} 1(\mathrm{OH})$ atoms with neighboring electronegative atoms. Since these atoms are used in a strong intramolecular hydrogen bonding, the charge densities may be increased. As a result of theoretical calculations, the fact that both the $\mathrm{N} 1$ and N3 atoms are more negatively charged than the $\mathrm{N} 2$ atom and the $\mathrm{O} 1$ atom than the $\mathrm{O} 2$ atom support the intermolecular interactions within the crystal obtained by X-ray diffraction. According to these results, it is possible to say that these atoms play an important role in the formation of intermolecular hydrogen bonds.

Schiff bases obtained from aldehydes containing o-hydroxy group have two types of tautomeric structures: enol-imine and keto-amine. The presence of these two types structures was also determined by UV-VIS spectral analysis. It is known that electronic transitions occurring below $400 \mathrm{~nm}$ are enol-imine transitions and electronic transitions above $400 \mathrm{~nm}$ are keto-amine forms [40].

In our study, UV-VIS spectra (Fig. 11) of $\mathrm{C}_{30} \mathrm{H}_{30} \mathrm{~N}_{3} \mathrm{O}_{2} \mathrm{SCl}$ molecule were recorded in ethanol and it was determined that $\mathrm{C}=\mathrm{C}, \mathrm{N}-\mathrm{N}$ and $\mathrm{C}=\mathrm{O}$ groups may belong to 
Table 7 Mulliken, ESP, NPA and Hirshfeld charges

\begin{tabular}{|c|c|c|c|c|}
\hline Atoms & Mulliken & ESP & NPA & Hirshfeld \\
\hline 01 & -0.543518 & -0.620822 & -0.67014 & -0.07609 \\
\hline $\mathrm{O} 2$ & -0.316729 & -0.476052 & -0.56762 & -0.2496 \\
\hline N1 & -0.376231 & -0.464844 & -0.38205 & -0.081197 \\
\hline $\mathrm{N} 2$ & -0.320716 & -0.076626 & -0.28657 & 0.001814 \\
\hline N3 & -0.3982 & -0.144398 & -0.55112 & -0.17071 \\
\hline S1 & 0.345211 & 0.086626 & 0.44333 & 0.082128 \\
\hline $\mathrm{Cl} 1$ & -0.039878 & -0.109578 & -0.02771 & -0.08903 \\
\hline $\mathrm{C} 1$ & 0.283861 & 0.62824 & 0.39746 & 0.090429 \\
\hline $\mathrm{C} 2$ & -0.209474 & -0.308187 & -0.23809 & 0.005857 \\
\hline $\mathrm{C} 3$ & -0.192083 & -0.222032 & -0.12912 & 0.029339 \\
\hline $\mathrm{C} 4$ & 0.042201 & 0.108398 & -0.08012 & -0.015333 \\
\hline $\mathrm{C} 5$ & -0.211168 & -0.225695 & -0.16081 & 0.009711 \\
\hline $\mathrm{C} 6$ & -0.193433 & -0.149512 & -0.20627 & -0.001056 \\
\hline $\mathrm{C7}$ & -0.198985 & -0.087315 & -0.17624 & 0.007563 \\
\hline $\mathrm{C} 8$ & -0.226593 & -0.337852 & -0.19679 & -0.002904 \\
\hline $\mathrm{C} 9$ & 0.001138 & 0.370369 & -0.0088 & $-1.01 \mathrm{E}-4$ \\
\hline C10 & -0.135345 & -0.684995 & -0.17873 & -0.049288 \\
\hline C11 & 0.037169 & 0.631222 & 0.11473 & 0.076351 \\
\hline $\mathrm{C} 12$ & 0.506353 & 0.718559 & 0.69702 & 0.177285 \\
\hline C13 & -0.635 & -0.458508 & -0.43425 & 0.110769 \\
\hline C14 & 9 & 73 & 0.2 & 0.104748 \\
\hline C15 & -0.489673 & -0.40026 & -0.41578 & -0.02537 \\
\hline C16 & 0.255446 & 0.082715 & 0.15582 & 0.024414 \\
\hline $\mathrm{C} 17$ & -0.288577 & 0.101774 & -0.22575 & 0.00405 \\
\hline C18 & -0.397613 & -0.426924 & -0.36538 & 0.013357 \\
\hline C19 & -0.38624 & -0.481257 & -0.35452 & 0.015278 \\
\hline $\mathrm{C} 20$ & -0.136972 & 1.102273 & -0.03828 & 0.007235 \\
\hline $\mathrm{C} 21$ & -0.596149 & -0.537262 & -0.55688 & 0.011724 \\
\hline $\mathrm{C} 22$ & 0.042416 & -0.799344 & -0.05055 & -0.017391 \\
\hline $\mathrm{C} 23$ & 0.092553 & 0.503086 & -0.00317 & -0.008579 \\
\hline $\mathrm{C} 24$ & -0.231652 & -0.584253 & -0.20522 & -0.021639 \\
\hline $\mathrm{C} 25$ & 0.07507 & 0.474382 & -0.01024 & -0.011029 \\
\hline $\mathrm{C} 26$ & -0.231643 & -0.569096 & -0.20464 & -0.020895 \\
\hline $\mathrm{C} 27$ & 0.09357 & 0.454103 & -0.00155 & -0.007661 \\
\hline $\mathrm{C} 28$ & -0.721792 & -0.453566 & -0.57494 & 0.021466 \\
\hline $\mathrm{C} 29$ & -0.678798 & -0.433329 & -0.5703 & 0.030066 \\
\hline C30 & -0.722128 & -0.388889 & -0.57546 & 0.023827 \\
\hline $\mathrm{H} 1$ & 0.429121 & 0.391567 & 0.49022 & 0.137013 \\
\hline $\mathrm{H} 11$ & 0.312528 & -0.150880 & 0.22710 & 0.047622 \\
\hline
\end{tabular}

$\pi \rightarrow \pi^{*}$ and $\mathrm{n} \rightarrow \pi^{*}$ transitions. The two major maximum peaks observed in the experimental UV-VIS spectra are at $306.57 \mathrm{~nm}$ (molar absorption coefficient; $\varepsilon=2800 \mathrm{~L}$ / $\mathrm{mol} \mathrm{cm}$ ) and $277.24 \mathrm{~nm}$ (molar absorption coefficient; $\varepsilon=3050 \mathrm{~L} / \mathrm{mol} \mathrm{cm}$ ). These values correspond to the transitions $n \rightarrow \pi^{*}$ and $\pi \rightarrow \pi^{*}$, respectively. This result supports that the molecule crystallizes in enol-imine form and agree with similar molecule [41]. Using the DFT method, these peaks were theoretically obtained

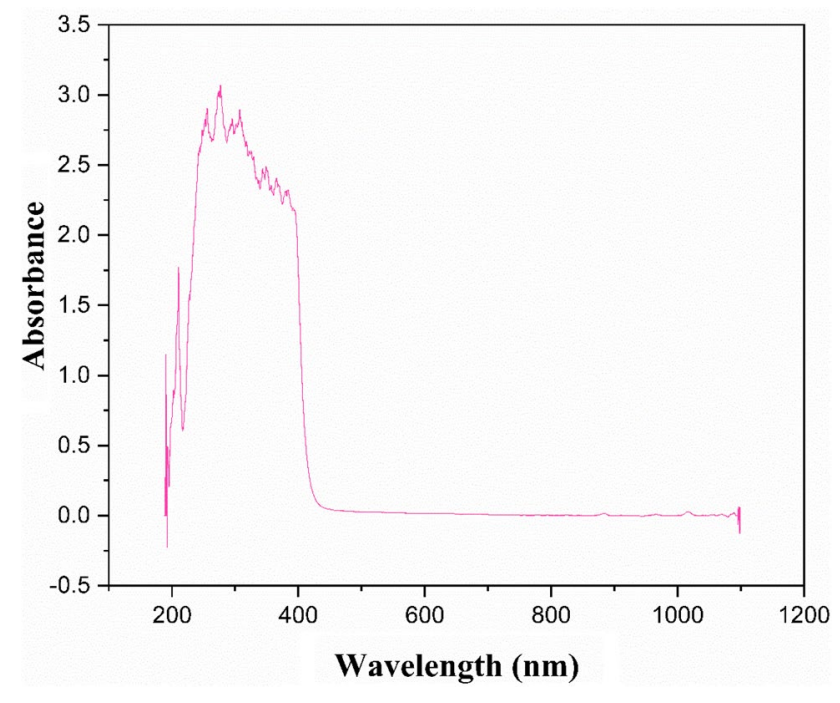

Fig. 11 Experimental UV-Vis spectrum

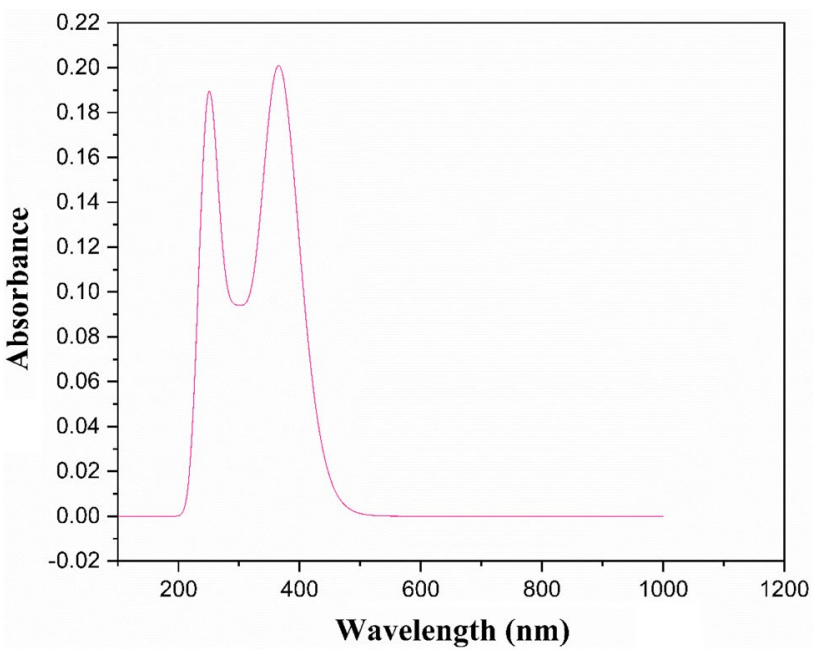

Fig. 12 Theoretically UV-Vis spectrum

at $366.93 \mathrm{~nm}(\varepsilon=20,089 \mathrm{~L} / \mathrm{mol} \mathrm{cm})$ and $249.13 \mathrm{~nm}$ $(\varepsilon=18,833 \mathrm{~L} / \mathrm{mol} \mathrm{cm}$ ) (Fig. 12) and the two peaks correspond to the electron transitions $\mathrm{HOMO} \rightarrow$ LUMO (98\%) for $366.93 \mathrm{~nm}$ and HOMO-6 $\rightarrow$ LUMO (9\%), HOMO-5 $\rightarrow$ LUMO (60\%), HOMO-4 $\rightarrow$ LUMO (2\%), HOMO-4 $\rightarrow$ LUMO + 2 (3\%), HOMO-3 $\rightarrow$ LUMO + 1 (2\%), $\mathrm{HOMO}-3 \rightarrow \mathrm{LUMO}+2$ (4\%), HOMO $\rightarrow$ LUMO +3 (16\%) for $249.13 \mathrm{~nm}$. The experimental and calculated two major maximum peaks of UV-Vis spectral data (excitation energies, wavelength, oscillator strength) were showed comparatively in Table 8.

The HOMO and LUMO orbitals and energy values of the title compound are given in Fig. 13. As it is seen, the orbitals, which the molecule react by giving electron, 
Table 8 Experimental and calculated absorption wavelength $(\lambda \max )$, excitation energies (E), Oscillator strength (f), assignment and Excited State of the title compound

\begin{tabular}{|c|c|c|c|c|c|}
\hline \multirow{2}{*}{$\begin{array}{l}\text { Major excited state and } \\
\text { contributions }\end{array}$} & \multirow[t]{2}{*}{$E(e V)$} & \multicolumn{2}{|c|}{ Wavelength (nm) } & \multirow{2}{*}{$\begin{array}{l}\text { Oscillator } \\
\text { strength (f) }\end{array}$} & \multirow[t]{2}{*}{ Assignment } \\
\hline & & Experimental & Calculated & & \\
\hline \multicolumn{6}{|l|}{ Excited state-1 } \\
\hline $\mathrm{H} \rightarrow \mathrm{L}(\% 98)$ & 3.379 & 306.57 & 366.93 & 0.4850 & $\mathrm{n} \rightarrow \pi^{*}$ \\
\hline \multicolumn{6}{|l|}{ Excited state-2 } \\
\hline $\mathrm{H}-6 \rightarrow \mathrm{L}(\% 9)$ & 4.977 & 277.24 & 249.13 & 0.2570 & $\pi \rightarrow \pi^{*}$ \\
\hline \multicolumn{6}{|l|}{$\mathrm{H}-5 \rightarrow \mathrm{L}(\% 60)$} \\
\hline \multicolumn{6}{|l|}{$\mathrm{H}-4 \rightarrow \mathrm{L}(\% 2)$} \\
\hline \multicolumn{6}{|l|}{$\mathrm{H}-4 \rightarrow \mathrm{L}+2(\% 3)$} \\
\hline \multicolumn{6}{|l|}{$\mathrm{H}-3 \rightarrow \mathrm{L}+1(\% 2)$} \\
\hline \multicolumn{6}{|l|}{$\mathrm{H}-3 \rightarrow \mathrm{L}+2(\% 4)$} \\
\hline$H \rightarrow L+3(\% 16)$ & & & & & \\
\hline
\end{tabular}

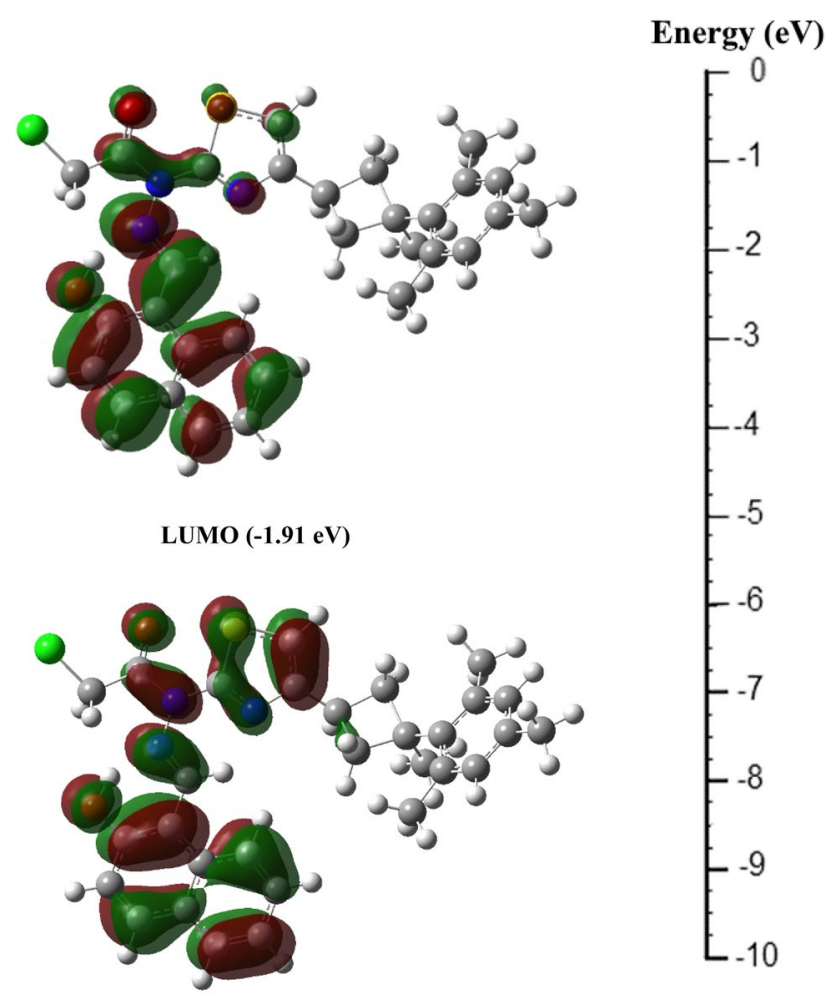

HOMO (-5.72 eV)

Fig. 13 HOMO and LUMO orbitals

are located on thiazole and naphthalene rings and the orbitals, which the molecule react by taking electron, are located on naphthalene, thiazole rings and $\mathrm{N}$ atoms. These orbitals on the compound indicate the regions where nucleophilic and electrophilic attacks occur.
The MEP map of the molecule was obtained using the DFT/B3LYP/6-31G(d) method and is shown in Fig. 14a, b. In the MEP map, negative regions (red, yellow) are on $\mathrm{O}$ and $\mathrm{S}$ atoms, while positive regions (blue) are on hydrogen atoms. The most negative region is on $\mathrm{O}$ atoms and the maximum MEP value is -0.050 a.b., while the MEP value for $S$ atom is -0.035 a.b. and these results indicate that $O$ and $\mathrm{S}$ atoms are the most suitable regions for electrophilic reaction. The maximum MEP value in the positive region on the $\mathrm{H}$ atoms bound to the benzene and naphthalene rings was calculated as +0.023 a.b.. According to these results, the nucleophilic and electrophilic regions determined by net charge analysis, Frontier orbitals (FMO) and MEP analysis are in good agreement with each other.

\subsection{Thermodynamic parameters of the title compound}

Scheme 1 shows the complete synthesis scheme of the title compound. Heat capacity $\left(C_{m}^{0}\right)$, entropy $\left(S_{m}^{0}\right)$ and enthalpy $\left(H_{m}^{0}\right)$ values, which are the standard thermodynamic functions for each reagent and products in the formation reaction, were calculated and are listed in Table 9, while enthalpy change $(\Delta \mathrm{H})$, Gibbs free energy change $(\Delta \mathrm{G})$ and entropy change $(\Delta \mathrm{S})$ values were calculated and are listed in Table 10. As can be seen in Table 9, the standard heat capacity, entropy and enthalpy of reactance and products were calculated between 100 and $500 \mathrm{~K}$ temperature and it is seen that the $\left(C_{m}^{0}\right),\left(S_{m}^{0}\right)$ and $\left(H_{m}^{0}\right)$ values increase as the temperature increases. In Table 10, the $\Delta S$ values of the title compound are negative in all temperature and the $\Delta \mathrm{H}$ values are positive. This result indicates that the formation of the title compound occurs between 


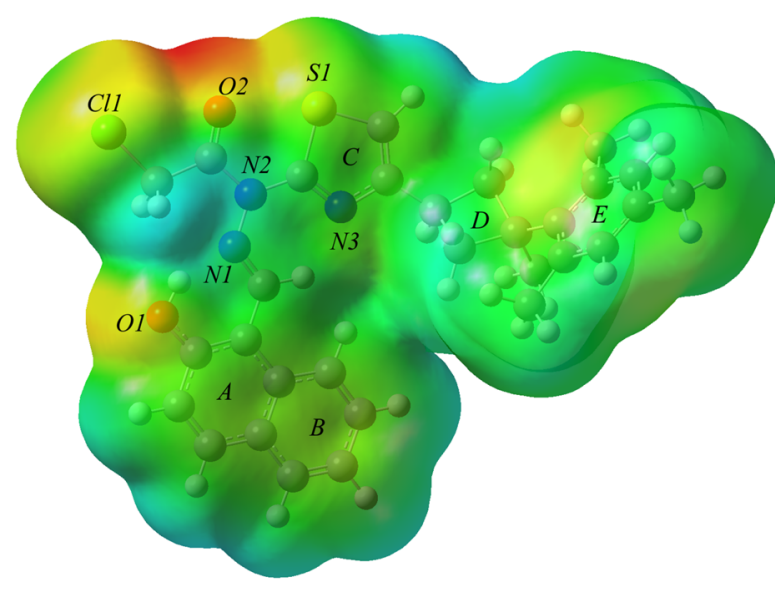

(a)

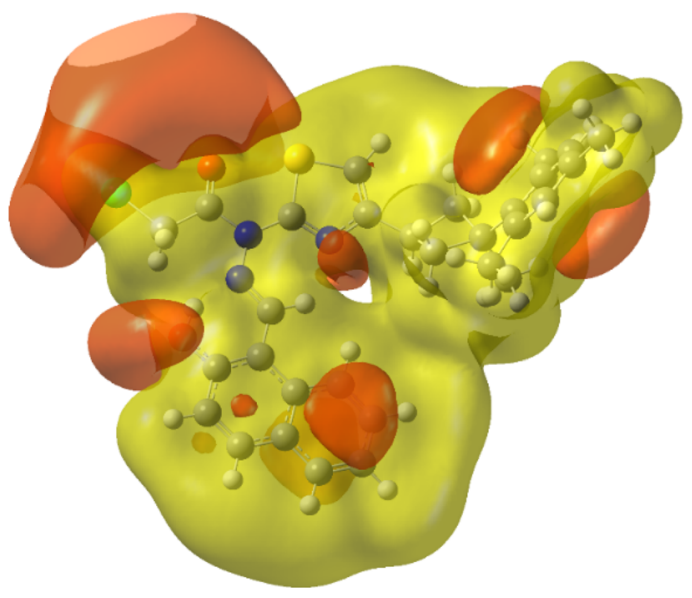

(b)

Fig. 14 a MEP map (blue arrow), b secondary MEP map derived from electron density

100 and $500 \mathrm{~K}$ by an endothermic process. Using the $\Delta \mathrm{G}=\Delta \mathrm{H}-\mathrm{T} \Delta \mathrm{S}$ equation, Gibbs free energy change $(\Delta \mathrm{G})$ was also obtained between 100 and $500 \mathrm{~K}$ temperatures. In Table 10 , the $\Delta \mathrm{G}$ values above $100 \mathrm{~K}$ temperature are positive $(\Delta G>0)$, indicating that the formation process of the title compound is not spontaneous.

According to the data in Table 9, The correlations equations of the $C_{m}^{0}, S_{m}^{0}$ and $H_{m}^{0}$ versus $T$ temperatures were obtained as follows; by $\Delta \mathrm{H}<0$ and $\Delta \mathrm{S}<0$. However, $\Delta \mathrm{H} \simeq 0$ and $\Delta \mathrm{S}>0$ are caused by an electrostatic force [42]. In our study, negative values of calculated $\Delta \mathrm{H}$ and $\Delta \mathrm{S}$ at temperatures corresponding to $100-500 \mathrm{~K}$ range indicate that van der Waals force or hydrogen bond interactions may play an important role in binding the title compound to a receptor. In addition, negative values of $\Delta \mathrm{G}$ indicate the nature of the spontaneous formation of the binding process [43].

$H_{m}^{0}=-2.040884+0.083518 \mathrm{~T}+7.321438 \times 10^{-4}, \mathrm{~T}^{2}\left(\mathrm{R}^{2}=0.999984\right)$

$C_{m}^{0}=50.983585+1.649169 T-3095901 \times 10^{-4}, T^{2}\left(R^{2}=0.999749\right)$

$S_{m}^{0}=311.759639+2.134661 \mathrm{~T}-5.93033 \times 10^{-4}, \mathrm{~T}^{2}\left(\mathrm{R}^{2}=0.999887\right)$

The values $C_{m}^{0}, S_{m}^{0}$ ve $H_{m}^{0}$ can be obtained at all other temperatures with these equations. Also, their correlation graphs are shown in Fig. 15.

The sign and size of these thermodynamic parameters are useful for determining the intermolecular binding mode (particularly receptor-ligand interactions). It has been reported that a hydrophobic interaction is characterized by $\Delta \mathrm{H}>0$ and $\Delta \mathrm{S}>0$ and van der Waals force or hydrogen bond formation is characterized

\section{Conclusions}

In this study, molecular structure of chloro-acetic acid $N^{\prime}--$ (2-hydroxy-naphthalen-1-ylmethylene)-N-[4-(3-methyl-3phenyl-cyclobutyl)-thiazol-2-yl]-hydrazide crystal has been determined by X-ray diffraction and IR, NMR and UV-Vis spectroscopic methods. In addition, spectroscopic spectra were obtained theoretically. Finally, the Mulliken, ESP, NPA and Hirshfeld charge distributions, molecular electrostatic potential and FMO were investigated. The geometric 
Table 9 Thermodynamic properties of the reactants and products at various temperatures

\begin{tabular}{|c|c|c|c|c|}
\hline Structure & Temperature (K) & $H_{m}^{0}(\mathrm{~kJ} / \mathrm{mol})$ & $C_{m}^{0}(\mathrm{~J} / \mathrm{molK})$ & $S_{m}^{0}(\mathrm{~J} / \mathrm{molK})$ \\
\hline \multicolumn{5}{|l|}{ Reactants } \\
\hline \multirow[t]{11}{*}{ A } & 100 & 11.82218756 & 196.196128 & 469.9477779 \\
\hline & 150 & 23.50811085 & 273.006 & 563.7145103 \\
\hline & 200 & 38.84793544 & 348.92468 & 651.4883447 \\
\hline & 250 & 57.86437204 & 426.111112 & 736.0686482 \\
\hline & 298.5 & 79.70198381 & 500.954504 & 815.7782137 \\
\hline & 350 & 107.0557753 & 579.747592 & 900.2257886 \\
\hline & 400 & 137.0641968 & 651.716576 & 980.2772309 \\
\hline & 450 & 170.4085695 & 718.342592 & 1058.764084 \\
\hline & 500 & 206.8113183 & 779.098456 & 1135.432958 \\
\hline & ZPE & 1289.003 & & \\
\hline & $E$ & -4520436.958 & & \\
\hline \multirow[t]{11}{*}{ B } & 100 & 3.820446525 & 40.08272 & 246.0667834 \\
\hline & 150 & 6.34890585 & 48.500928 & 266.4788353 \\
\hline & 200 & 9.273540937 & 56.450528 & 283.2468835 \\
\hline & 250 & 12.56911766 & 64.0152 & 297.9274726 \\
\hline & 298.5 & 16.07666104 & 70.87696 & 310.7418169 \\
\hline & 350 & 20.19487024 & 77.69688 & 323.4676755 \\
\hline & 400 & 24.47457784 & 83.654896 & 334.8903804 \\
\hline & 450 & 29.02429058 & 89.002048 & 345.6051994 \\
\hline & 500 & 33.81877433 & 93.780176 & 355.7046403 \\
\hline & ZPE & 98.277 & & \\
\hline & $E$ & -2816705.973 & & \\
\hline \multicolumn{5}{|l|}{ Products } \\
\hline \multirow[t]{11}{*}{ C (title compound) } & 100 & 13.26810293 & 223.710112 & 501.440658 \\
\hline & 150 & 26.48069078 & 308.712256 & 607.4867982 \\
\hline & 200 & 43.71055132 & 391.835784 & 706.0920919 \\
\hline & 250 & 64.95768458 & 476.022048 & 800.5988868 \\
\hline & 298.5 & 89.25814695 & 557.379928 & 889.3018215 \\
\hline & 350 & 119.5920886 & 642.792104 & 982.9478915 \\
\hline & 400 & 152.7724396 & 720.61032 & 1071.469833 \\
\hline & 450 & 189.5562236 & 792.51236 & 1158.04911 \\
\hline & 500 & 229.6381077 & 857.966856 & 1242.472552 \\
\hline & ZPE & 1364.799 & & \\
\hline & $E$ & -6127579.111 & & \\
\hline \multirow[t]{11}{*}{ D } & 100 & 2.79594105 & 20.786112 & 148.8772616 \\
\hline & 150 & 4.196434988 & 20.786112 & 160.2195249 \\
\hline & 200 & 5.594405513 & 20.786112 & 168.2677054 \\
\hline & 250 & 6.992376038 & 20.786112 & 174.5099723 \\
\hline & 298.5 & 8.339878313 & 20.790296 & 179.4370193 \\
\hline & 350 & 9.7908405 & 20.79448 & 183.9256597 \\
\hline & 400 & 11.18881103 & 20.811216 & 187.6621713 \\
\hline & 450 & 12.58930496 & 20.848872 & 190.9602763 \\
\hline & 500 & 13.99232231 & 20.915816 & 193.9165045 \\
\hline & ZPE & 16.847 & & \\
\hline & $E$ & -1209588.697 & & \\
\hline
\end{tabular}

$E$ total energies $\left(\mathrm{kJ} \mathrm{mol}^{-1}\right) ; Z P E$ zero point energies $\left(\mathrm{kJ} \mathrm{mol}^{-1}\right)$ 
Table 10 The entropy, enthalpy and free energy change of the formation reaction

\begin{tabular}{llll}
\hline Temperature & $\Delta \mathrm{H}(\mathrm{kJ} / \mathrm{mol})$ & $\Delta \mathrm{S}(\mathrm{kJ} / \mathrm{molK})$ & $\Delta \mathrm{G}(\mathrm{kJ} / \mathrm{mol})$ \\
\hline 100 & -30.089590 & -0.065696 & -23.519925 \\
150 & -29.690891 & -0.062487 & -20.317837 \\
200 & -29.327520 & -0.060375 & -17.252433 \\
250 & -28.994429 & -0.058887 & -14.272613 \\
298.5 & -28.691620 & -0.057781 & -11.472825 \\
350 & -28.378716 & -0.056819 & -8.4917469 \\
400 & -28.088524 & -0.056035 & -5.6742810 \\
450 & -27.798332 & -0.055359 & -2.8863774 \\
500 & -27.510663 & -0.054748 & -0.1363915 \\
\hline
\end{tabular}

${ }^{*} \Delta H=\left(H_{m}^{0}+Z P E+E\right)_{\text {product }}+\left(H_{m}^{0}+Z P E+E\right)_{\text {product }}-\left(H_{m}^{0}+Z P E+E\right.$ )$_{\text {reaktant } A}-\left(H_{m}^{0}+Z P E+E\right)_{\text {reaktantB }}$

${ }^{*} \triangle S=\left(S_{m}^{0}\right)_{\text {productC }}+\left(S_{m}^{0}\right)_{\text {productD }}-\left(S_{m}^{0}\right)_{\text {reaktantA }}-\left(S_{m}^{0}\right)_{\text {reaktantB }}$

${ }^{*} \Delta G=H_{m}^{0}-T \Delta S$
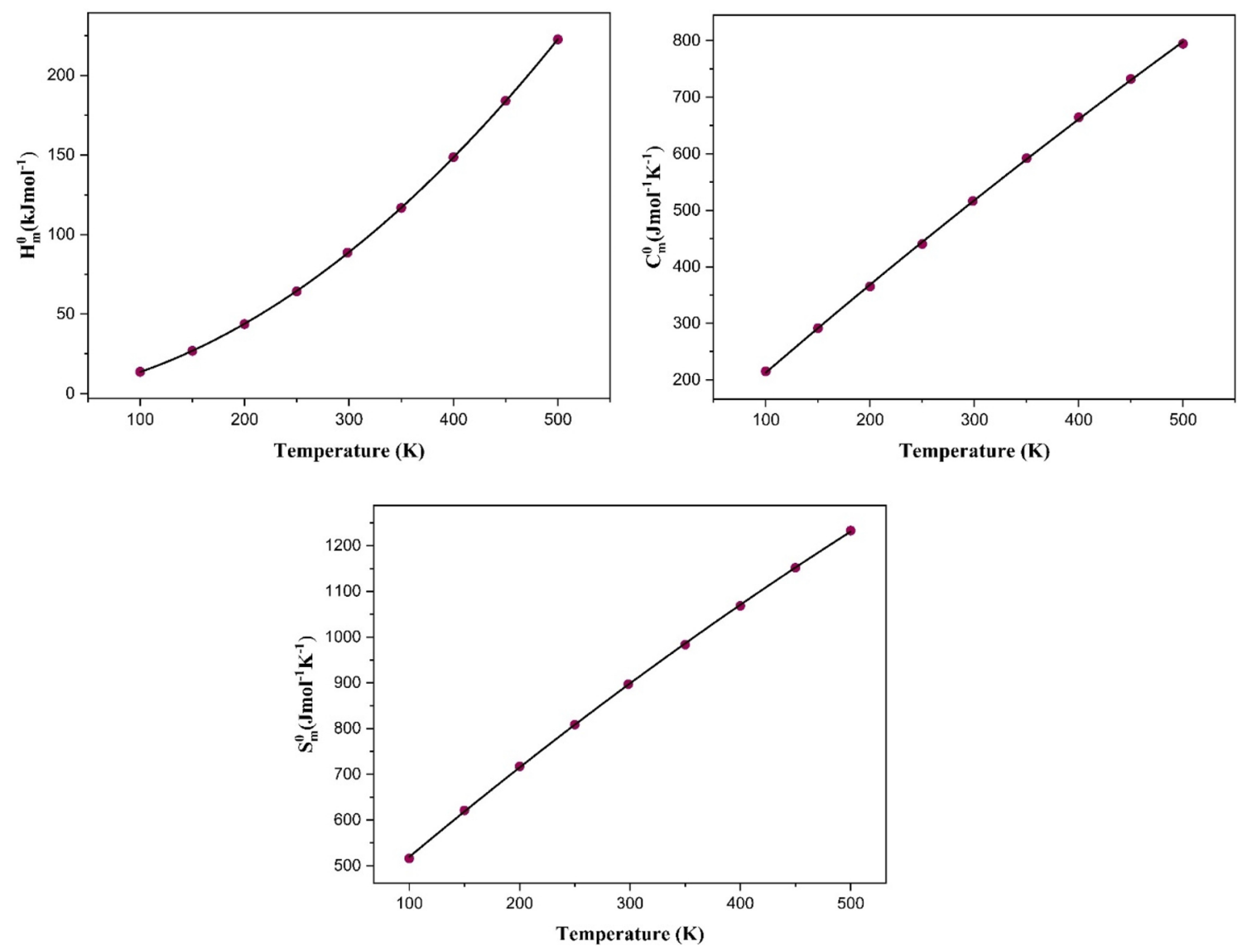

Fig. 15 Correlation graphs of the $C_{m^{\prime}}^{0} S_{m}^{0}$ and $H_{m}^{0}$ versus various temperatures 
Acknowledgements Computing resources used in this work were provided by the National Center for High Performance Computing of Turkey (UHeM) under Grant Number <5005172018>.

\section{Compliance with ethical standards}

Conflict of interest The author(s) declare that they have no competing interests.

\section{References}

1. Hargrave KD, Hess FK, Oliver JT (1983) N-(4-Substituted-thiazolyl) oxamic acid derivatives, new series of potent, orally active antiallergy agents. J Med Chem 26(8):1158-1163

2. Jaen JC, Wise LD, Caprathe BW, Tecle H, Bergmeier S, Humblet CC, Heffner TG, Meltzer LT, Pugsley TA (1990) 4-(1, 2, 5, 6-Tetrahydro-1-alkyl-3-pyridinyl)-2-thiazolamines: a novel class of compounds with central dopamine agonist properties. J Med Chem 33(1):311-317

3. Patt WC, Hamilton HW, Taylor MD, Ryan MJ, Taylor DG Jr, Connolly CJ, Doherty AM, Klutchko SR, Sircar I (1992) Structureactivity relationships of a series of 2-amino-4-thiazole-containing renin inhibitors. J Med Chem 35(14):2562-2572

4. Bell FW, Cantrell AS, Hoegberg M, Jaskunas SR, Johansson NG, Jordan CL, Kinnick MD, Lind P, Morin JM Jr (1995) Phenethylthiazolethiourea (PETT) compounds, a new class of HIV-1 reverse transcriptase inhibitors. 1 . Synthesis and basic structure-activity relationship studies of PETT analogs. J Med Chem 38(25):4929-4936

5. Tsuji K, Ishikawa H (1994) Synthesis and anti-pseudomonal activity of new 2-isocephems with a dihydroxypyridone moiety at C-7. Bioorg Med Chem Lett 4(13):1601-1606

6. Badorc $A$, Bordes $M-F$, de Cointet $P$, Savi $P$, Bernat $A$, Lalé $A$, Petitou M, Maffrand J-P, Herbert J-M (1997) New orally active non-peptide fibrinogen receptor (Gpllb-IIla) antagonists: identification of ethyl 3-[N-[4-[4-[amino [(ethoxycarbonyl) imino] methyl] phenyl]-1, 3-thiazol-2-yl]-N-[1-[(ethoxycarbonyl) methyl] piperid-4-yl] amino] propionate (SR 121787) as a potent and long-acting antithrombotic agent. J Med Chem 40(21):3393-3401

7. Tapia RA, Prieto Y, Pautet F, Walchshofer N, Fillion H, Fenet B, Sarciron M-E (2003) Synthesis and antiprotozoal evaluation of benzothiazolopyrroloquinoxalinones, analogues of kuanoniamine A. Bioorg Med Chem 11(16):3407-3412

8. Srivastava S, Yadav R, Srivastava S (2004) Synthesis and biological activity of 4-oxothiazolidines and their 5-arylidenes. Indian J Chem 43B:399-405

9. Siddiqui HL, Zia-Ur-Rehman M, Ahmad N, Weaver GW, Lucas PD (2007) Synthesis and antibacterial activity of Bis [2-amino4-phenyl-5-thiazolyl] Disulfides. Chem Pharmaceut Bull 55(7):1014-1017

10. Kayagil I, Demirayak S (2009) Synthesis and anticancer activities of some thiazole derivatives. Phosphorus Sulfur Silicon 184(9):2197-2207

11. Misra RN, Xiao H-y, Williams DK, Kim KS, Lu S, Keller KA, Mulheron JG, Batorsky R, Tokarski JS, Sack JS (2004) Synthesis and biological activity of $\mathrm{N}$-aryl-2-aminothiazoles: potent pan inhibitors of cyclin-dependent kinases. Bioorg Med Chem Lett 14(11):2973-2977

12. El-Subbagh $\mathrm{Hl}$, Abadi AH, Lehmann J (1999) Synthesis and antitumor activity of ethyl 2-substituted-aminothiazole-4-carboxylate analogs. Archiv der Pharmazie Int J Pharmaceut Med Chem 332(4):137-142
13. Gorczynski MJ, Leal RM, Mooberry SL, Bushweller JH, Brown ML (2004) Synthesis and evaluation of substituted 4-aryloxyand 4-arylsulfanyl-phenyl-2-aminothiazoles as inhibitors of human breast cancer cell proliferation. Bioorg Med Chem 12(5):1029-1036

14. Schrauzer GN, Kohnle J (1964) Coenzym B12-modelle. Chem Ber 97(11):3056-3064

15. Çukurovali A, Taş E, Ahmedzade M (1997) The synthesis and some transition metal complexes of tolyl $n$-imidazolylmethyl ketoxime. Synth React Inorg Metal Chem Org 27(8):1115-1166

16. Cie S (2002) X-area (version 1.18) and X-red32 (version 1.04). Darmstadt, Germany

17. Sheldrick GM (2015) SHELXT-integrated space-group and crystal-structure determination. Acta Crystallogr Sect A Found Adv 71(1):3-8

18. Sheldrick GM (2015) Crystal structure refinement with SHELXL. Acta Crystallogr Sect C Struct Chem 71(1):3-8

19. Dolomanov OV, Bourhis LJ, Gildea RJ, Howard JA, Puschmann $H$ (2009) OLEX2: a complete structure solution, refinement and analysis program. J Appl Crystallogr 42(2):339-341

20. Frisch $M$, Trucks $G$, Schlegel HB, Scuseria G, Robb M, Cheeseman J, Scalmani G, Barone V, Mennucci B, Petersson G (2009) Gaussian 09, revision A. 02, Gaussian. Inc., Wallingford, CT 200

21. Hohenberg P, Kohn W (1964) Inhomogeneous electron gas. Phys Rev 136(3B):B864

22. Lee C, Yang W, Parr RG (1988) Development of the Colle-Salvetti correlation-energy formula into a functional of the electron density. Phys Rev B 37(2):785

23. Becke AD (1993) Density-functional thermochemistry. III. The role of exact exchange. J Chem Phys 98(7):5648-5652

24. Foresman JB, Frisch A (1996) Exploring chemistry with electronic structure methods, 2nd edn. Gaussian Inc., Pittsburg

25. Dennington R, Keith T, Millam J, Eppinnett K, Hovell WL, Gilliland R (2009) GaussView, Version

26. Giannozzi P, Baroni S, Bonini N, Calandra M, Car R, Cavazzoni C, Ceresoli D, Chiarotti GL, Cococcioni M, Dabo I (2009) QUANTUM ESPRESSO: a modular and open-source software project for quantum simulations of materials. J Phys Condens Matt 21(39):395502

27. Perdew JP, Burke K, Ernzerhof M (1996) Generalized gradient approximation made simple. Phys Rev Lett 77(18):3865

28. Perdew JP, Zunger A (1981) Self-interaction correction to density-functional approximations for many-electron systems. Phys Rev B 23(10):5048

29. Sun Y-X (2006) 4-(5-Chloro-2-hydroxybenzylideneamino)-1, 5-dimethyl-2-phenyl-1H-pyrazol-3 (2H)-one. Acta Crystallogr Sect E Struct Rep Online 62(12):05858-05859

30. Sun Y-X, Zhang R, Jin Q-M, Zhi X-J, Lü X-M (2006) 4-(4-Chlorobenzylideneamino)-1, 5-dimethyl-2-phenyl-1H-pyrazol-3 (2H)-one and 4-(2-chlorobenzylideneamino)-1, 5-dimethyl-2-phenyl$1 \mathrm{H}$-pyrazol-3 (2H)-one. Acta Crystallogr Sect C Cryst Struct Commun 62(8):0467-0469

31. Cukurovali A, Karakurt T (2019) Synthesis, spectroscopic, X-ray diffraction and tautomeric properties of 5-(diethylamino)-2((2-(5-(3-methyl-3-phenylcyclobutyl)-6H-1, 3, 4-thiadiazin-2yl) hydrazono) methyl) phenol: a combined experimental and theoretical study. J Mol Struct 1189:328-337

32. Karakurt T, Cukurovali A, Subasi NT, Onaran A, Ece A, Eker S, Kani I (2018) Experimental and theoretical studies on tautomeric structures of a newly synthesized 2, 2'(hydrazine-1, 2-diylidenebis (propan-1-yl-1-ylidene)) diphenol. Chem Phys Lett 693:132-145

33. Dewar MJ, Zoebisch EG, Healy EF, Stewart JJ (1985) Development and use of quantum mechanical molecular models. 76. AM1: a new general purpose quantum mechanical molecular model. J Am Chem Soc 107(13):3902-3909 
34. Monkhorst HJ, Pack JD (1976) Special points for Brillouin-zone integrations. Phys Rev B 13(12):5188

35. Rabie UM, Abou-EI-Wafa MH, Nassar H (2012) Interaction of thiazolidine-2-thione with 2, 3, 5, 6-tetrabromo-1, 4-benzoquinone: a set of sequential interactions involving redox and substitution reactions after an initial charge transfer complexation. Spectrochim Acta Part A Mol Biomol Spectrosc 86:252-255

36. Lambert JB, Shurvell HF, Lightner DA, Cooks RG (1987) Introduction to organic spectroscopy. Macmillan Publishing Company, New York

37. Dabbagh HA, Teimouri A, Chermahini AN, Shahraki M (2008) DFT and ab initio study of structure of dyes derived from 2-hydroxy and 2,4-dihydroxy benzoic acids Spectrochim. Acta Part A Mol Biomol Spectrosc 69:449

38. Karakurt T, Cukurovali A, Subasi NT, Kani I (2016) Molecular structure and computational studies on 2-((2-)(4-(3-(2, 5-dimethylphenyl)-3-methylcyclobutyl) thiazol-2-yl) hydrazono) methyl) phenol monomer and dimer by DFT calculations. J Mol Struct 1125:433-442

39. Yilmaz I, Çukurovali A (2003) Salicylaldehyde thiazolyl hydrazones as ligands. Heteroat Chem Int J Main Group Elem 14(7):617-621
40. Ünver $H$ (2001) Synthesis and spectroscopic studies in some new Schiff bases. Spectr Lett 34(6):783-791

41. Joshi H, Kamounah FS, Gooijer C, van der Zwan G, Antonov L (2002) Excited state intramolecular proton transfer in some tautomeric azo dyes and schiff bases containing an intramolecular hydrogen bond. J Photochem Photobiol A Chem 152(1-3):183-191

42. Ross PD, Subramanian S (1981) Thermodynamics of protein association reactions: forces contributing to stability. Biochemistry 20(11):3096-3102

43. Mohamadi M, Faghih-Mirzaei E, Ebrahimipour SY, Sheikhshoaie I, Haase W, Foro S (2017) Synthesis, spectroscopic studies, DFT calculations, electrochemical evaluation, BSA binding and molecular docking of an aroylhydrazone-based cis-dioxido Mo (VI) complex. J Mol Struct 1139:418-429

Publisher's Note Springer Nature remains neutral with regard to jurisdictional claims in published maps and institutional affiliations. 